\title{
A Psicologia no Brasil
}

\section{Antonio Rodrigues Soares}

\section{ÍNDICE}

PRÓLOGO

INTRODUÇÃO

CAPÍTULO I - A Pré-História da Psicologia, no Brasil..................................................12

CAPÍTULO II - A história da Psicologia escrita por Médicos.....................................13

CAPÍTULO III - A história da Psicologia escrita por Educadores................................17

CAPÍTULO IV - A Psicologia na Legislação Nacional .............................................19

CAPÍTULO V - Os Encontros das Sociedades de Psicologia.......................................22

CAPÍTULO VI - Eleição, posse e atividades do Primeiro Conselho Federal............26

CAPÍTULO VII - Eleição, posse e atividades do Segundo Conselho Federal..........31

CONCLUSÃO

BIBLIOGRAFIA 
Já em franco desenvolvimento de suas atividades, o Primeiro Conselho Federal de Psicologia me encomendava a elaboração de uma HISTÓRIA DO CONSELHO. Era o ano de 1975.

Por acreditar ainda muito cedo para se fazer história com os caracteres de isenção de ânimo, frieza de análise e objetividade absoluta de informação, fui deixando para mais tarde o início da empreitada, na certeza de que só os pósteros é que poderiam emitir parecer sobre homens e obras que, sem dúvida, merecem a admiração de todos e o aplauso da classe inteira, por quanto realizaram em favor da Profissão e da Ciência psicológicas.

Ademais, o Conselho Federal desponta dentro de um contexto histórico e numa moldura cultural, dos quais é o resultado necessário e a necessária síntese. Sua história, por consequência, resultará de uma profunda e intensa pesquisa de documentos que, no Brasil já trazem as marcas dos séculos, pois, têm raizes nas primeiras atividades acadêmicas das Faculdades de Medicina da Bahía e do Rio de Janeiro, onde, em se filosofando, se haveria de deparar com a vetusta Psicologia Racional, berço primeiro e seio gerador da Psicologia Científica. Através dela, de fato, impulsionada pelas contribuições das ciências de experiência e afins, é que, em 1879, dava seus primeiros passos a Psicologia Ciêntifica.

Em 1978, quando da reunião do Conselho Federal de Psicologia, em Belo Horizonte, uma preocupação tomava corpo na mente dos Senhores Conselheiros pelo avizinhar-se da sua última etapa de atividades, como Segundo Conselho: comemorar condignamente o Centenário da Psicologia, como ciência. Foi nesse momento que, uma vez mais, fui incumbido de escrever algo de natureza histórica sobre a nossa Autarquia.

Entendendo que caberia à solicitação e à comemoração da efeméride, pelo menos, uma crônica (que mais não poderia ser feito) sobre a curta vida do Conselho, aceitei o pedido dos meus pares.

Ao começar a escrever, logo percebi, em meio à riqueza de documentos manuscritos e impressos, em meio ao produto de natureza acadêmica e de provimento de cátedra, em meio aos documentos oficiais e às notas históricas e, mais tarde, em meios ao acervo de pesquisas e de achados, que já se poderia, e mesmo se deveria, envidar esforços para publicar uma obra de fôlego sobre o passado e o presente da Psicologia no Brasil.

Nomes, obras, feitos estão, na verdade, à espera do historiador que os ressuscite e os faça acessíveis a alunos, professores de Psicologia e grande público, pondo a claro a evolucao de uma Ciencia e sua necessidade, sobretudo, em meio à nossa sociedade em franca mutação.

Fica o desafio lançado para todos. A história merece mais páginas para enriquecer de Psicologia seus juízos e suas informações. A Psicologia merece mais uma história, com mais fatos e mais valores, para favorecer a iluminação de sua gestação, através do tempo, entre nós.

O presente trabalho, pela sua dimensão e simplicidade, não quer ser mais que um Ensaio de Psicologia, no Brasil, com todas as lacunas de que temos consciência, quer quanto a nomes 
de mérito, quer quanto a obras publicadas, quer quanto a institutos, ainda hoje, em franca atividade científica. Essas lacunas se assoberbam, quando nos encontramos em meio ao acervo das Faculdades de Medicina, cujas produções mereceriam ou uma tese ou um volume sobre as Contribuições Psicológicas das suas dissertações, tamanho o seu número e significado.

Temos ciência, portanto, das carências destas páginas. Mas só as escrevemos movidos pelo interesse de informar nossos colegas de Profissão de como nasceu e se impôs, entre nós, a Psicologia e seu Conselho Profissional.

Esperamos que, em atendendo a quanto nos solicitou o Conselho Federal de Psicologia, estas páginas sirvam, modestamente, de consagração e louvor a quantos, antes de nós, fizeram ciência e a quantos, antes de nós, plantaram as raízes de uma Classe, cuja imagem e valor e unidade e privaticidade de direitos específicos precisamos entregar às gerações que, amanhã, nos sucederão. 


\section{A Psicologia no Brasil}

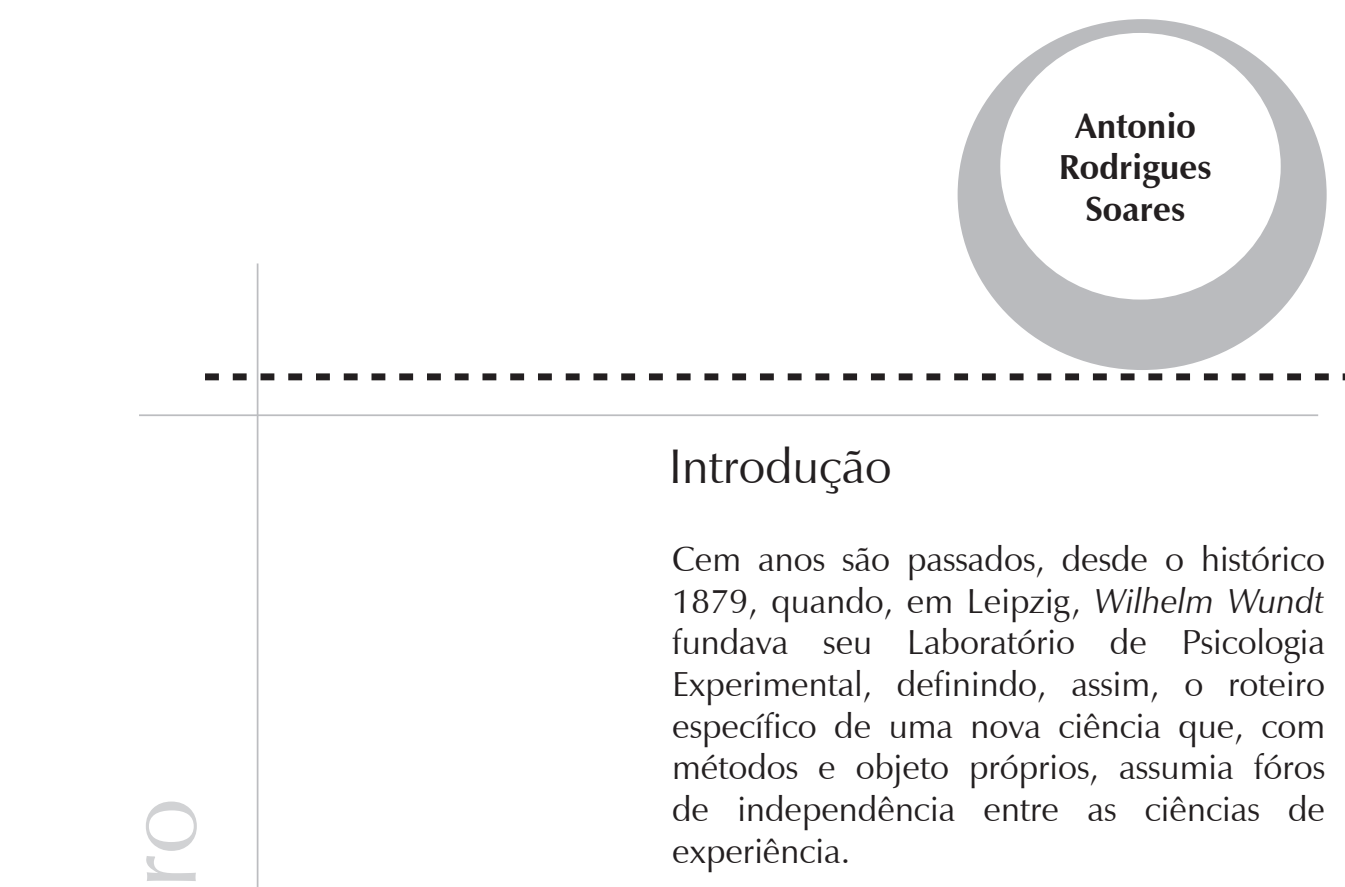

A gestação longa e penosa por que passou a Psicologia, vinculada à Filosofia, desde os momentos primeiros do pensamento humano, cedeu lugar ao grande entusiasmo das primeiras pesquisas do seu conteúdo e à sua primeira sistematização que, elaborada por Wundt e continuada pelos seus discípulos, parecia delimitar os horizontes do seu interesse e explicitar as dimensões teleológicas da sua atividade.

É com o vigor das incipientes experiências, enriquecidas pela multissecular tradição filosófica e progressiva indagação fisiológica, que a Psicologia penetra nos terrenos do ensino oficial.

Como, no entanto, a ciência abstém-se de indagações que não se fundamentem nem se configurem em fatos, cedo emergiu a constatação da insuficiência dos dados em acervo, ao lado da fragilidade de muitos 
elementos tidos como definitivos. As controvérsias geradas pela diversidade das posições culturais que permeavam o hábito mental de quantos se acercavam da Psicologia, desencadearam uma luta sem quartéis contra o método e o objeto da nova ciência, levando os devassadores dos seus limiares a desconfiarem dela como sistematização típica e completa. Os saudosistas da especulação aumentaram, ainda, a litania dos pessimistas quanto à sua continuidade e persistência, como ciência autônoma, e com direito a lugar no concerto das ciências, ora reclamando seu retorno ao seio de origem, ora profetizando o reencontro da filha pródiga com a mãe insubstituível, após os passos experimentais indevidos e mal ensaiados.

A Psicologia, todavia, desiludiu àqueles futurólogos, emigrando para a Inglaterra e Estados Unidos, com a, então, significativa bagagem científica dos alunos de Wundt. De aí, caminhou os mais diversos caminhos, adquirindo cidadania, hoje, em quase todos os países do mundo.

As duas matrizes de que procedeu a Psicologia são, indubitavelmente, a Filosofia e a Fisiologia. E isto é, de tal forma, evidente que a mesma Psicologia parece, atualmente, ser a grande ponte de contato entre as duas e um como modelo dialógico entre a especulação e a experimentação. Encontra-se aqui a posição de tropeço para a jovem ciência: é ela portadora da unilateralidade das ciências de análise e da amplitude das ciências de pensamento e de síntese.

À medida, porém, que a Psicologia se consolida, dentro dos marcos de sua especificidade, aceitando as limitações que lhe são impostas pelos seus métodos e pelos imperativos dos dados de ordem superior, próprios da experiência humana, abre-se definida, entre as ciências de análise e de síntese, a moldura em que se vai, a pouco e pouco, inserindo, definitiva, a ciência do comportamento. De fato, não se faz Psicologia sem Fisiologia e sem Filosofia, vez que os fatos psíquicos estão vinculados, inseparavelmente, com os biológicos, sem, entretanto, com eles se confundirem. São, ainda, os fatos psíquicos o pressuposto e o resultado de um pensamento que, por ser peculiaridade humana, é portador do caráter humano irredutível, por isso mesmo, ao especificamente biológico.

Não estamos a asserir, (nem poderíamos fazê-lo), que a Psicologia se confunda ou dependa da Filosofia, ou que uma seja, absolutamente, necessária para a existência da outra. Ao contrário, defendemos a independência de ambas as ciências, suas peculiaridades de objeto e método. Insistimos em mostrar a influência que a Filosofia exerceu (e continuará a exercer) sobre a Psicologia, vez que esta é resultado da elaboração do homem que sente e age de acordo com o que pensa, e vive atufado num processo cultural que não se configuraria nem se distinguiria, sem uma "Weltanschauug" que a consolidasse.

As várias Escolas psicológicas, que são as veias e o sangue alimentadores do grande organismo da nova ciência, partem de critérios e finalidades diversas, quando tratam do mesmo elemento de análise. Cada uma manteve-se coerente com seus pontos de vista. Psicofísica e Psicofisiologia procuraram mais o conteúdo da vida psíquica que seu caráter unitário. A Escola Gestáltica buscou a vinculação dos diversos fatos psicológicos, opondo-se ao atomismo. O Funcionalismo, o Behaviorismo, a Psicologia Compreensiva, procuram mais o aspecto concreto e prático, em sua pesquisa. A Psicanálise investiga os dinamismos inconscientes mais que os conscientes. As caracterologias procuram o indivíduo, na variedade e na unidade dos seus caracteres.

As Escolas são todas criaturas do seu ambiente filosófico, são todas resultantes da cultura em que nasceram. Daqui brotam os grandes percalços com que se defronta a Psicologia, na abordagem do seu objeto; dificuldades que se somam às limitações criadas pelos métodos de pesquisa, pelas condições ambientais e pela mentalidade e formação filosófica dos pesquisadores. 
No Brasil, a Psicologia está à espera de amplas pesquisas que Ihe ofereçam pegadas seguras e modelos típicos, caracterizadores de um nível de evolução onde se engendrem escolas e descobertas autóctones, como aconteceu em outras nações, em condições econômico-culturais superiores às nossas.

O historiador, entretanto, que se entregar à beneditina tarefa de repassar as andanças da Psicologia, entre nós, disporá de documentos bastantes para a elaboração de um relato histórico do que, aqui, aconteceu, desde os primeiros momentos de uma Psicologia, simplesmente especulativa, até os cometimentos da experimentação que, hoje, se desdobram e se avantajam, em vários pontos do País.

Para efeito deste Ensaio, que se insere no calendário das comemorações com que o Conselho Federal de Psicologia quer festejar o Centenário da Psicologia Científica, dividimos a História da Psicologia, no Brasil, em sete capítulos:

I - A Pré-história (1830 - 1900)

II - A História escrita por Médicos (1900 - 1920)

III - A História escrita por Educadores (1920 - 1960)

IV - A Psicologia na Legislação Nacional (1890 - 1977)

V - Os Encontros das Sociedades de Psicologia (1971 — 1973)

VI - Eleição, posse e atividades do Primeiro Conselho Federal (1973-1976)

VII - Eleição, posse e atividades do Segundo Conselho Federal (1976-1979).

\section{CAPÍTULO I}

\section{A pré-história da psicologia, no Brasil (1830 - 1900)}

As primeiras contribuições para o estudo da Psicologia, no Brasil, são oferecidas por Médicos. Em suas teses de doutoramento (assim eram denominados os trabalhos de conclusão de curso, nas Faculdades de Medicina), nas teses de provimento de cátedra e nas teses de verificação de títulos, incursionavam, estudantes e profissionais, sobretudo no Rio de Janeiro e Bahia, nas seáras da Psicologia, (evidentemente, racional ou filosófica), trazendo a lume achados e conclusões de interesse não só para o filósofo e historiador, como para o homem de cultura.

Entusiasma-nos observar como, então, não se desdenhava da Filosofia por se a reconhecer como a "mater scientiarum", mesmo nas especialidades médicas e por se saber que, sem ela, empobrece o pensamento, padece a lógica, esbate-se a dialética, morre a crítica, apouca-se a criatividade, sofisma-se a verdade.

No Rio de Janeiro, os estudos da Faculdade de Medicina tendiam para a Neuropsiquiatria, a Psicofisiologia e a Neurologia. Dentro dessas instâncias, se situava a maioria das teses defendidas, entrando, não raro, a Psicologia a ser analisada em suas relações com aqueles campos de estudo e pesquisa.

Em 1836, Manuel Inácio de Figueiredo Jaime defende tese que nos reporta, de imediato, à obra quase homônima de René Descartes: "Paixões e Afetos da Alma". José Augusto César de Menezes doutora-se, em 1834, com o trabalho: Proposições a Respeito da Inteligência". 
I. M. Sechenov, célebre Fisiólogo e Psicólogo russo estabelecia os fundamentos da Psicofisiologia dos órgãos dos sentidos, traçando caminhos novos e originais. Ocupou-se dos processos, também, psíquicos e das leis do seu desenvolvimento como objeto principal da Psicologia. Em sua obra, Reflexos do Cérebro e, em outros trabalhos, procurou solucionar o isolamento do psiquismo, com os meios à disposição, na época. Sua influência foi notável em muitos países. E Guedes Cabral, em 1876, defende tese sob o título: "Funções de Cérebro".

Na Alemanha, em 1879, Wundt abria seu Laboratório de Psicologia Experimental, incorporado, pouco depois, à Universidade de Leipzig. Nesse Laboratório formaram-se os homens mais eminentes da nova ciência, tanto alemães (Kraepelin, Lehmann, Külpe, Neumann) e americanos (Cattel, Stanley Hall, Titchener, Warren, Stratton e outros). O Laboratório edita sua revista: Philosophische Studien, encerrada em 1903 e, mais tarde, reaberta como título: "Archiv für die gesamte Psychologie". O intenso trabalho de pesquisa lá desenvolvido e a obra de Wundt determinaram, através dos seus alunos, grande influência, em vários países.

Pouco mais de uma década, após o início das atividades de Wundt e seus discípulos, no Rio de Janeiro, começam a aparecer teses de doutoramento em que a envergadura científica é bastante apreciável. Em 1890, José Estelita Tapajós defende a tese: Psicofisologia da Percepção e das Representações. Veríssimo de Castro, disserta sobre: Das Emoções. O interesse elementarístico dos primórdios da Psicologia Científica tem suas ressonâncias características nessas teses. Em 1891, Odilon Goulart escreve o primeiro trabalho, no Brasil, de Psicologia Clínica: Estudo Psicoclínico da Afasia. Já no campo da memória, o primeiro trabalho brasileiro surge, em 1894, quando Alberto Seabra defende a tese: A Memória e a Personalidade.

\section{CAPÍTULO II}

\section{A história da psicologia escrita por médicos (1900 - 1920)}

Na primeira metade do século XIX, segundo os historiadores de Medicina, maior era o pendor para concepções e sistemas - embora sempre com a disposição e persuasão a trabalhar com os dados experimentais disponíveis - . Pelo meado do século, se acentuou um organizado progresso da ciência e arte médicas, em virtude da especialização e ânimo voltados, preferencialmente, para experimentos em laboratório. No Brasil, sobretudo com os egressos das Faculdades de Medicina do Rio de Janeiro e da Bahia, isto se comprova sobejamente, quer pelos trabalhos de preenchimento de cátedra, quer pelas iniciativas, extraordinariamente importantes, que esses médicos levaram a termo em muitas Instituições.

Em meados do nosso século, Ivan Petrovitch Pavlov inicia estudos que alcançam a vasta gama dos reflexos condicionados, analisadores cerebrais, inibição interna e neurose experimental, tanto do ponto de vista teórico quanto do estritamente experimental, sempre em referência direta à Psicologia. Sua influência, no campo científico, foi definitiva, suscitando inúmeras pesquisas, em todas as partes, e determinando nascimento de Escolas, também na área da Psicologia.

Nas pegadas da Psicologia Experimental, que acabara de nascer, com o laboratório de Leipzig, e que tinha em Pavlov um novo nume, as teses da Faculdade do Rio de Janeiro recebem profunda influência. A figura de Henrique Roxo distingue-se pela defesa do primeiro trabalho de Psicologia Experimental: Duração dos Atos Psíquicos, em 1900, apresentando uma posição extremamente atual, ao propor que a Psiquiatría tenha por propedêutica a Psicologia Científica. 
Henrique Roxo tem o mérito de haver sido, também, o primeiro a orientar, no Brasil, os estudos práticos com testes, usando as provas de Binet-Simon, no Hospício Nacional. Foi ele o organizador do laboratório de experimentação psicológica, junto à cátedra de Psiquiatria. Dele partiram a idéia e o esforço de associar a Psicologia Experimental à Neurologia e à Psiquiatria.

A Faculdade de Medicina da Bahia foi fundada pela Carta Régia de 18 de fevereiro de 1808, com a denominação de Escola de Cirurgia, passando a chamarse Academia Médico-Cirúrgica, por outra Carta Régia do mesmo D. João VI, em 29 de dezembro de 1815. Tornou-se Faculdade, por ato da Regência Trina, em 30 de outubro de 1832.

Os estudos, naquela Casa, norteavam-se, de preferência para a aplicação social da Psicologia, para a Criminologia, para Psiquiatria Forense e Higiene Mental.

Nos cinco lustros que medeiam entre 1840 e 1900, mais de quarenta teses foram defendidas, com abordagem de temas psicológicos. Entre estas, encontram-se as teses de doutoramento e as celebradas teses de provimento de cátedra.

A biblioteca da Faculdade foi totalmente consumida por incêndio, às 9:30 hs da noite de 2 para 3 de março de 1905. Naquela data possuía 15.000 volumes.

O povo se comoveu com o evento, ajudando a reconstituição do acervo que, na sua inauguração, em 30 de abril de 1909, já contava com 12.000 volumes. Acadêmicos e professores, como afirma Otávio Torres, em seu trabalho: Esboço histórico dos acontecimentos mais importantes da vida da Faculdade de Medicina da Bahia (1808-1946), "obtiveram valiosas ofertas de livros, obras de medicina, teses, e fizeram também a aquisição de numerosas outras obras e revistas médicas" (p. 51).

Em 1851, Francisco Tavares da Cunha escreve o primeiro ensaio sistemático de Psicofisiologia, no Brasil: Psicofisiologia acerca do Homem.

Ernesto Carneiro Ribeiro, em 1864, faz-se arauto da necessidade da pesquisa psicológica para a formação do médico, com a tese: Relação da Medicina com as Ciências Filosóficas: Legitimidade da Psicologia, numa excelente antevisão do problema da interdisciplinaridade, como fator de aperfeiçoamento cultural e profissional.

Entre 1853 e 1888, a Faculdade de Medicina da Bahia produz alguns trabalhos que antecedem, em conteúdo e perspectivas, o problema da interação indivíduo-cultura, tão evidenciado, nos nossos dias, pelas conhecidas posições de celebrados psicanalistas culturalistas: Fromm, Horney, Sullivan. Referem-se essas teses à Influência da Civilização no Movimento das Doenças Mentais.

Vem a lume, em 1897, a obra: Epilepsia e Crime, que fez seu autor, Júlio Afrânio Peixoto, conhecido no Brasil e no Exterior.

Por não estar ligada, com exclusividade, a esse ou àquele centro europeu, a Faculdade de Medicina da Bahia, recebia influência benéfica de várias correntes doutrinárias. Seu progresso deveu-se, precisamente, à sua independência de escolas sistemáticas. 
A partir da primeira década de 1900, as teses, ensaios e atividades dos médicos, saídos das duas Faculdades, Rio e Bahia, trazem caráter científico mais preciso e interesse Psicológico mais definido, pelo uso de métodos e técnicas de Psicologia de maior objetividade e confiabilidade.

Começam a surgir os Laboratórios de Psicologia, em hospitais, Clínicas Psiquiátricas. A apreciabilidade dos resultados da produção e resultados psicológicos leva o próprio Governo, não raras vezes, a se interessar pela sua criação.

A tese de Maurício Campos Medeiros, defendida, em 1907, no Rio de Janeiro, prova a tendência a um maior rigor científico: Métodos em Psicologia.

A primeira história da Psicologia, no Brasil, tem por título: A Psicologia Experimental no Brasil. Seu autor, defende, em 1911, tese com o título: Associação de Idéias. Trata-se de Plínio Olinto, a quem o Rio de Janeiro deve a criação, no Instituto de Educação, do Laboratório para Cursos de Psicologia Geral e Clínica.

Ao retornar da Europa, onde estudara com Georges Dumas, Maurício de Medeiros, conhecedor de metodologia de pesquisa e técnicas projetivas, dedica-se completamente à Psicologia. Será ele a propor, quatro décadas mais tarde, à Universidade do Brasil a criação de cursos de Psicologia Normal, nas Clínicas Psiquiátricas.

Por incumbência de Juliano Moreira, Maurício instala o Laboratório de Psicologia Experimental na Clínica Psiquiátrica do Hospício Nacional e será seu primeiro Diretor.

O ano de 1922 assiste à criação da Liga Brasileira de Higiene Mental, responsável pela promoção das "Jornadas Brasileiras de Psicologia". Tentava, assim, a Liga despertar interesse pela pesquisa pura e pela pesquisa aplicada.

Dez anos depois, a Liga propõe ao Ministério da Educação e Saúde a criação obrigatória de Gabinete de Psicologia, junto às Clínicas Psiquiátricas. Como se vê, inovações que, nos nossos dias, trazem para o seio da Psicologia e para a Profissão largo campo de atividade e de melhoria científica, através da abordagem do homem e seu ajustamento, têm raízes bastante antigas, na ação de pioneiros.

O Ministério de Educação e Saúde avoca a si, com a denominação de Instituto de Psicologia, o Laboratório de Psicologia do Engenho de Dentro, que funcionou de 1923 a 1932, e preparou profissionais de diversas especialidades. Foi o primeiro centro brasileiro de pesquisa pura, em Psicologia. Seus equipamentos foram trazidos de Paris e Leipzig. O conhecido nome, na História da Psicologia do Brasil, Waclaw Radecki, polonês, foi o primeiro Diretor desse Laboratório que, em 1937, seria incorporado à Universidade do Brasil. Nomes quais os de Antonio Pena, Eliezer Schneider e Nilton Campos ali produziram trabalhos de relevo.

A doutrina de Sigmund Freud foi também fonte e objeto de atividade científica nas Faculdades de Medicina. A primeira tese, nelas defendida, foi a dissertação, em 1914, de Genserico de Souza Pinto: Da Psicanálise: A Sexualidade das Neuroses, no Rio de Janeiro. É o primeiro trabalho, em Português, sobre Psicanálise. 
A difusão, entretanto, das idéias psicanalíticas se processaria em virtude dos trabalhos de Francisco Franco da Rocha, em São Paulo, 1918; e de Júlio Porto Carreiro, no Rio de Janeiro, 1928.

Durval Marcondes, Lourenço Filho, Franco da Rocha, entre outros, fundam, em 1927, a Sociedade Brasileira de Psicanálise, que não duraria muito.

Um nome de médico, entre tantos citados, de mérito incontestável para a história da Psicologia, no Brasil, é o de Franco da Rocha. Consideramo-lo um pioneiro em dois campos de atividades afins: na Psicologia, iniciando a aplicação hospitalar de técnicas psicológicas e psiquiátricas; na Psiquiatria, realizando o trabalho de assistência à família do psicopata, hoje empregado, como absolutamente necessário, nos melhores centros, fóra do País.

As duas célebres Faculdades de Medicina, Rio de Janeiro e Bahia, tiveram, em seus bancos, nomes que ilustram e honram a Medicina Brasileira e a Ciência Psicológica. Bastem citados, entre outros: no Rio, Deolindo Couto, Pernambuco Filho, Antonio Austregésilo, Costa Rodrigues; na Bahia, Raimundo Nina Rodrigues, Juliano Moreira, Afrânio Peixoto e Arthur Ramos. Este, um dos expoentes da Psicologia nacional, entre diversos trabalhos de valor, publicaria, em 1952, uma Introdução à Psicologia Social.

Em várias cidades criam-se Institutos, onde os estudos de Psicologia e a aplicação de técnicas psicológicas são promovidos por nomes que merecem compor a galeria dos que, na qualidade de Médicos, fizeram Psicologia, neste País.

Em Recite, Ulisses Pernambucano criou, em 1925, o Instituto de Seleção e Orientação Profissional que, posteriormente, receberia a denominação de Instituto de Psicologia, aberto até 1936. Com Pernambucano trabalharam e se especializaram: Silvio Rabelo, Anita Barreto e Nelson Pires. Pernambucano e seus auxiliares aplicavam provas de nível mental e de aptidão, entre outros instrumentos psicológicos. As pesquisas de Psicologia Aplicada produzidas pelo Instituto fazem parte do nosso acervo histórico.

Em Minas Gerais, em 1929-1930, o Secretário de Educação, Ministro Francisco Campos traz ao Brasil, através de uma missão que enviara à Europa, Claparéde, Léon Walter e T. H. Simon. Estes professores de renome ministraram curso de Psicologia Educacional e reorganizaram, na Escola Normal, o Laboratório de Psicologia que funcionava desde 1927.

Quando Claparède retorna à Europa, Helena Antipoff o substitui no laboratório, produzindo inúmeros trabalhos que atravessaram, também, nossas fronteiras.

Em São Paulo, com a criação do Instituto de Higiene, médicos da estatura intelectual de um Banjamim Ribeiro e de um Paula Souza levam a termo, a partir de 1927, estudos de Psicologia Aplicada, originando, através dos seus resultados, o Serviço de Inspeção Médico-Escolar, onde, onze anos mais tarde, Durval Marcondes, criaria a primeira Clínica de Orientação Infantil. Uma vez mais, o passado ensina ao presente: esse Serviço manteve uma Escola para Deficientes Mentais.

Em Porto Alegre, a Universidade Federal do Rio Grande do Sul instituí, graças a Décio de Souza, ex-aluno de Wertheimer, Murphy, Salomon e Kohler, a cadeira de Psicologia, nos cursos de 
Medicina. Nesse Estado trabalhou, a partir de 1933, Martim Comes, realizando pesquisas na área da Psicologia Médica.

O ano de 1940 funge de divisor de águas entre o autoditatismo e a preparação específica. Mas, só a partir de 1950, no campo médico, é que se criam as cadeiras de Psicologia.

\section{CAPÍTULO III}

\section{A história da psicologia escrita por educadores e suas escolas normais}

\section{$(1920-1960)$}

Da atividade de Educadores, de sólida cultura científica, e do trabalho das Escolas Normais se haveria de fecundar a Psicologia Brasileira, através da dedicação à cátedra, do amanho das novas inteligências e do preparo de pesquisas, nas mais diversas áreas da educação e da experimentação psicológica. Foram mestres que, criando gerações de profissionais em Educação e em Psicologia, projetaram seus nomes no cenário nacional e fora dele.

Em São Paulo, as Escolas Normais têm seu lugar na história da Psicologia Brasileira, quer pelos nomes que as dirigiram, quer pela produção científica delas oriunda.

A Escola Normal de São Paulo recebeu a colaboração de Ugo Pizzoli que veio ao Brasil a convite de Oscar Thompson, em 1913. Ugo Pizzoli, catedrático da Universidade de Módena, Itália, criou, ao chegar a São Paulo, o Laboratório de Pedagogia Experimental. Ao lado da preparação de inúmeros pesquisadores, ministrou cursos de Psicometria, retornando à pátria, onze anos depois.

Pizzoli foi substituído na Escola Normal por Clemente Quaglio e, no laboratório, por Sampaio Dória. O valor do trabalho de Pizzoli e do Laboratório, que dirigiu, pode ser bem apreciado pela obra, de 1927, Psychologia Experimental.

A Psicologia, entre nós, escreve um capítulo especial, com a fundação, em 1924, da Associação Brasileira de Educação, (obra de Heitor Lyra da Silva). No seu quadro social, a ABE reúne os nomes exponenciais de Lourenço Filho, Fernando de Azevedo e Anísio Teixeira, responsáveis pela grande revolução por que passou a Educação Nacional.

Cada um destes homens mereceria um volume que lhes analisasse a genialidade, os méritos e as obras.

Lourenço Filho iniciou seus estudos com testes de atenção e de maturidade para a leitura, na Escola Complementar de Piracicaba, que seria, depois, chamada de Escola Normal. Catedrático de Psicologia, em 1925, da Escola Normal de São Paulo, deu impulso e vida novos ao Laboratório organizado por Pizzoli. Até 1927, ano em que Henri Piéron chega a São Paulo para ministrar os cursos de Psicologia Experimental e Psicometria, Lourenço Filho leva a termo pesquisas experimentais e as primeiras experiências com o Teste ABC. Datam desse ano, as publicações: Contribuição ao Estudo Experimental do Hábito e Introdução ao Estudo da Escola 
Nova. Promoveu uma série de traduções das obras de grandes pedagogos, cuja fama chegava ao Brasil, mediante suas idéias. Kilpatrick, Durkheim, Ferriére e Binet-Simon têm, assim, seus livros à disposição do público brasileiro.

Dirigindo a educação, em São Paulo, reorganiza o ensino e cria cursos de aperfeiçoamento para professores, exigindo se ministrem, neles, as disciplinas: Psicologia e Sociologia.

Para trabalhar ao seu lado, Lourenço Filho convida Noemi Rudolpher da Silveira e J. B. Damasceno Penna. Com Noemi, cria, na Escola Normal de São Paulo, o Laboratório de Psicologia Educacional.

Ao aceitar, em 1932, cargos de administração, na Educação Nacional, entrega a Noemi a cátedra e o Laboratório. Este, em 1934, (ano da criação da Universidade de São Paulo), é incorporado à cátedra de Psicologia Educacional da USP.

Anísio Teixeira confia, em 1938, a Lourenço Filho a orientação e seleção profissional, a nível nacional. Esta atividade teve seu início, no Instituto de Estudos Pedagógicos, onde Lourenço Filho cria um serviço especial, entregue a Murilo Braga, e um serviço de Psicologia Aplicada, sob a responsabilidade de Manuel Marques e, depois, Armando Hildebrand. É, ainda, obra de Lourenço Filho o Serviço de Medidas Escolares, no Instituto de Educação do Distrito Federal, que, mais tarde, passaria a constituir o Instituto de Pesquisas Educacionais.

Anísio Teixeira é um nome nacional. Não necessita que lhe demos nenhum adjetivo. Ai estão seus mais de 9 volumes publicados, inúmeros artigos e trabalhos que, como sua vida, foram todos dedicados à educação. Ai está o Diretor Geral da Instrução Pública do Distrito Federal, o Secretário de Educação da Bahia, o Ministro da Educação, o promovedor da revolução, na Educação Brasileira. Seu nome, entretanto, penetra na História, também da Psicologia, ao transformara Escola Normal do Distrito Federal em Instituto e, depois, em Instituto de Pesquisas Educacionais. Com Lourenço Filho dividia interesses psicológicos e pedagógicos.

Por influência de Medeiros e Albuquerque, Isaías Alves, outro baiano de envergadura cultural, dedicou-se ao estudo dos Testes, produzindo uma adaptação do Teste Binet-Simon (Versão Cyril Burt), após 1921. Na Escola Normal do Distrito Federal, transformada por Anísio em Instituto de Educação, montou um serviço de testes, que viria a produzir diversos estudos sobre testes e criar novos. Sua obra: Os testes e a Reorganização Escolar, foi publicada em 1930, saindo a $2^{\underline{a}}$ edição em 1934.

O iniciador da revolução educacional brasileira é Fernando de Azevedo, a partir de 1928. Ainda, nesta data, quando reformou o ensino do Distrito Federal, criou os Serviços de Orientação Profissional, nas Escolas Normais. Foi o primeiro a ensinar Sociologia, no Brasil.

Um nome ainda há de ser lembrado pela História da Psicologia: Arthur Ramos que trabalhou no Instituto de Pesquisas Educacionais. Ali estudou ortofonia. Sua obra: A criança Problema, foi publicada em 1939.

Merecem citados também, pelas suas obras em Psicologia e pela sua atividade de formadores de gerações novas: Djacir Menezes, no Ceará, que publicou, em 1938, o primeiro Dicionário de Psicologia Pedagógica; lago Pimentel, em Minas Gerais, que se distingue pelo seu livro: Psicologia Aplicada à Educação; na Escola Normal de Limeira; João de Souza Ferraz, com seus 
textos de Psicologia para o ensino normal, publicados desde 1941; na Escola de Piracicaba: José Rodrigues de Arruda, pioneiro de Estatística Educacional, no Brasil.

Em 1924, mais um pioneiro, em São Paulo, trabalhando em Psicologia Industrial, no Liceu de Artes e Ofícios, inicia farta produção científica no setor. É o engenheiro Roberto Mange, cujo trabalho, de 1930 a 1942, se desenvolveu no IDORT, na Estrada de Ferro Sorocabana e no Centro Ferroviário do Estado de São Paulo. Mange contou, no IDORT, com a colaboração de Anniela Ginsberg, em Psicologia Experimental e Clínica, em 1932; e, em 1933, de Betty Katzenstein, em Psicotécnica.

Mira Y Lopez cria, em 1947, no Rio de Janeiro, o Instituto de Seleção e Orientação Profissional (ISOP), na Fundação Getúlio Vargas. Das suas atividades científicas, surge, em 1946, a conhecida obra: Psicologia Evolutiva da Criança e do Adolescente.

Em São Paulo, Oswaldo de Barros Santos, autor do primeiro texto brasileiro de orientação profissional, dirige, de 1938 a 1942, o Gabinete de Psicotécnica da Escola Técnica Getúlio Vargas.

Finalmente, o País começa a contar com a instituição universitária, isto é, alguns homens se associam e se organizam para refletirem, em comum, os problemas e as necessidades do seu tempo, como o dissemos em recente Aula Inaugural. Em 1934, surge a Universidade de São Paulo e, no ano seguinte, a Universidade do Brasil. A cátedra de Psicologia do Instituto Caetano de Campos é incorporada à Universidade de São Paulo e Noemi Rudolpher da Silveira, que, em 1938, editaria sua Introdução à Psicologia Educacional, assume essa cátedra, de 1936 a 1954, formando uma plêiade de profissionais admiradores da mestra. Seu substituto foi Arrigo Leonardo Angelini. Já no curso de Filosofia, a cadeira de Psicologia é ocupada, de 1935 a 1944, por Jean Mangüé: por Klineberg de 1944 a 1947; e, a seguir, por Annita de Castilho e Marcondes Cabral.

O ano de 1954 é marcado por dois grandes eventos: cria-se a Associação Brasileira de Psicologia, a 10 de outubro, e o Arquivo Brasileiro de Psicologia publica o anteprojeto da lei sobre a formação de Psicólogo.

\section{CAPÍTULO IV}

\section{A psicologia na legislação nacional (1890 - 1977)}

Em 1890, a Reforma Benjamin Constant introduziu noções de Psicologia para a disciplina de Pedagogia, no currículo das Escolas Normais. Até 1910, a Psicologia era ensinada, juntamente com Lógica, nos seminários, nos colégios e nos chamados cursos "anexos" das Faculdades de Direito que previam essa matéria, em seus vestibulares. Mais tarde, fariam o mesmo as Faculdades de Medicina. O projeto de lei sobre o ensino obrigatório de Psicologia, nos cursos de Medicina, só apareceria em 1954, apresentado pelo Senador Marcondes Filho.

O Decreto-lei no 305, de 26 de fevereiro de 1938, em seu primeiro Considerando diz, "verbis", que o ensino superior da República deve ser reorganizado, de modo que se restrinja a sua quantidade às estritas exigências nacionais e se eleve a sua qualidade ao máximo de eficiência que o progresso econômico e espiritual do País, cada vez mais, reclama. 
O Decreto no 421, de 11 de maio do mesmo ano, regulamenta o funcionamento dos estabelecimentos de Ensino Superior. O artigo 4o , letras a, b, c, d, e, f, g, enumera os requisitos para autorização de organização e funcionamento de Curso Superior. Este Decreto é modificado pelo Decreto-lei no 2.076, de 8 de março de 1940. Merece destaque a modificação introduzida pelo art. 1ํㅡ, que condiciona a criação de curso à real necessidade imposta pelo meio.

Já o Decreto-lei no 9.092, de 26 de março de 1946, que "amplia o regime didático das Faculdades de Filosofia e dá outras providências", refere-se pela vez primeira, embora de forma incipiente, à Psicologia quando afirma, em seu artigo 4⿳⺈, parágrafo 1ํ: "Para obter o diploma de licenciado, os alunos do quarto ano receberão formação didática, teórica e prática, no Ginásio de Aplicação, e serão obrigados a um curso de Psicologia Aplicada à Educação".

O Senhor Ministro de Educação e Saúde, Ernesto de Souza Campos, expede, a 13 de abril de 1946, a Portaria no 272 que "aprova as instruções reguladoras da execução do disposto nos artigos 5ㅇ e 6으 do Decreto-lei no 9.092, de 26 de março de 1946". Diz a Portaria, em seu artigo 1: "Os diplomas de especialização, a que se refere o art. 5o do Decreto-lei de que trata esta Portaria, serão os seguintes: 1) Psicólogo; 2) Físico; 3) Químico; 4) Biólogo; 5) Geólogo; 6) Geógrafo; 7) Historiógrafo; 8) Etnógrafo; 9) Administrador Escolar.

E o Parágrafo Único: “Os candidatos que pretenderem o diploma de especialização deverão satisfazer às seguintes condições:

1) Psicólogo: Aprovado nos três primeiros anos do curso de Filosofia, bem como em cursos de Biologia, Fisiologia, Antropologia, Estatística, e em cursos especializados de Psicologia. Finalmente, estágio em serviços psicológicos, a juízo dos professores da seção".

O artigo 3ำ da mesma Portaria dispõe que "As Faculdades de Filosofia, que se regerem pelo sistema didático mandado adotar pelo Decreto-lei no 9.092, de 26 de março de 1946, poderão manter cursos de doutoramento, para bacharéis que se formaram pelo outro sistema, cujas exigências devem ser observadas".

A 13 de maio de 1946, através de Portaria no 328, o Senhor Ministro de Educação e Saúde "Resolve expedir anexas instruções, modificando e ampliando as expedidas pela Portaria $\mathrm{n}$ 272, de 13 de abril do corrente ano". No art. 10 desta Portaria, amplia-se a concessão de diplomas de especialização e se inclui, entre esses diplomas, o de Psicologia Educacional, para cuja consecução eram necessárias (no 1 do § único): aprovação nos 3 primeiros anos do curso de Pedagogia, aprovação em curso de Psicologia da criança e do adolescente, aprovação em Psicologia do Anormal, aprovação em curso de Psicologia da Personalidade, estágio em serviços de Psicologia Aplicada e frequência a seminário de métodos e pesquisas psicológicas".

O Senhor Ministro da Guerra, Canrobert Pereira da Costa, a 25 de outubro de 1949, faz publicar a Portaria no 171 com "instruções para o funcionamento do Curso de Classificação de Pessoal", com a inclusão do item: "Noções de Psicologia Normal e Patológica", com um repertório de assuntos de vasta área, partindo de objetivo e métodos de Psicologia, incursionando pela memória, raciocínio, imaginação, volição até Psicologia dos chefes militares".

Este Diploma legal assume extraordinária importância porque, em virtude de disposição legal ulterior, a que nos referiremos, outorga o DIPLOMA DE PSICÓLOGO. 
A Lei de Diretrizes e Bases da Educação Nacional, Lei no 4.024, de 20 de dezembro de 1961, estabelece disposições normativas, regulamentando, no Título IX, a estrutura do Ensino Superior e das Universidades.

O Presidente da República, João Belchior Goulart, promulga, a 27 de agosto de 1962, a Lei no 4.119. É o primeiro diploma legal específico sobre Cursos de Formação de Psicólogos. O texto da Lei traz significativas inovações, entre as quais, destacamos:

1 - permite aos portadores de diplomas ou certificados de especialista em Psicologia, Psicologia Educacional, Psicologia Clínica e Psicologia Aplicada ao Trabalho, o direito ao registro daqueles títulos, mediante a observância de outros requisitos (art. 19);

2 - determina que o registro deve ser requerido no prazo de 180 dias, a contar da publicação da Lei (art. 19, § 19);

3 - permite aos que já venham exercendo, na data da publicação da Lei, ou tenham exercido por mais de cinco anos, atividades profissionais de Psicologia Aplicada, o registro de Psicólogo, devendo o registro ser requerido, no prazo de 180 dias, após a publicação da Lei (art. 21).

O Presidente da República veta o $\S 1$ o do artigo 13 da Lei no 4.119, que trata da caracterização da função privativa do Psicólogo. Entretanto, o Congresso Nacional mantém, na sua íntegra, o parágrafo vetado.

O Conselho Federal de Educação, depois de ouvir o parecer do Conselheiro Valnir Chagas, relator da matéria, (Parecer n 403/62), fixa, mediante Resolução, o currículo mínimo e a duração do curso de Psicologia, com vigência a partir do ano de 1963 (art. 4⿳⺈).

A 9 de outubro de 1962, o Senhor Ministro de Educação e Cultura constitui, mediante Portaria no 227, a Comissão encarregada de opinar sobre os pedidos de registro de Psicólogo profissional, constituída pelos professores: Lourenço Filho, Enzo Azzi, posteriormente substituído por Arrigo Leonardo Angelini, Pedro Parafita Bessa, Antonius Benko S. J. e Carolina Matuscelli Bori.

Outra Portaria do Senhor Ministro de Educação e Cultura, no 228, de 27 de dezembro de 1962, publicada no Diário Oficial da União de 18 de março do mesmo ano, baixa "instruções para o registro de Psicólogos, no MEC". Essa Portaria, como se observa, foi publicada, após transcorridos os cento e oitenta (180) dias exigidos pela Lei no 4.119 , como prazo fatal para o requerimento do registro profissional de Psicólogo. Em consequência, todos os registros foram concedidos fora do prazo, mesmo porque a Comissão Constituída para opinar sobre os requerimentos, iniciou suas atribuições também fora do prazo, vez que lhe faltavam as instruções reguladoras. O prazo fatal tornou-se, portanto, letra morta.

O Senhor Ministro de Educação e Cultura, através de Portaria no 93, de 2 de julho de 1963, baixa instrução sobre a rotina a ser observada, no andamento dos processos de registro de Psicólogo, e estabelece outras providências.

A 21 de janeiro de 1964, o Senhor Presidente da República, promulga o Decreto no 53.464 que regulamenta a Lei no 4.119 . 
A Portaria no 103, de 8 de maio de 1964, do Senhor Ministro de Educação e Cultura, altera os artigos da Portaria no 93, de 2 de fevereiro de 1963, no que tange ao trabalho dos membros da Comissão. E, a 19 de novembro de 1964, expede o Ministro instruções para a realização das provas especiais a que se refere o parágrafo único do art. 23 da Lei no 4.119, de 27 de agosto de 1962. Pela Portaria no 285, de 11 de outubro de 1965, são dispensados os membros da Comissão designada para opinar sobre os registros de Psicólogo, em virtude da conclusão dos trabalhos. A 25 de janeiro de 1966, pela Portaria nP35, foi prorrogado o prazo, estabelecido na Portaria no 733, para a realização das provas teórico-práticas.

O Decreto-lei no 529, de 11 de abril de 1966, reabre, por sessenta (60) dias, o prazo para registro e proíbe os pedidos de revisão.

A 29 de dezembro de 1966, a Portaria do Senhor Ministro de Educação e Cultura de no 368, dispõe sobre os prazos para o último estudo dos processos de registro de Psicólogo. Nesta mesma data, o Diretor do Ensino Superior baixa Portaria, prorrogando o prazo de encaminhamento de requerimento do registro de Psicólogo profissional e reiterando a proibição de pedido de revisão dos processos.

Pelo Decreto-lei no 706, de 25 de julho de 1969, é estendido aos portadores de certificados de curso de pós-graduação, em Psicologia e Psicologia Educacional, o direito ao Registro Profissional de Psicólogo.

A Portaria no 3.286, de 1o de junho de 1970, prorroga, uma vez mais, até 31 de dezembro de 1971, o prazo para o competente registro de diploma, prazo esse relativo ao Decreto-lei no 529/66, cuja data fatal expirara a 14 de julho de 1969.

A 20 de dezembro de 1971, o Senhor Presidente da República, Emílio Garrastazú Médici, promulga a Lei no 5.766, que cria os Conselhos Federal e Regionais de Psicologia.

O Diretor do Departamento de Assuntos Universitários, Newton Sucupira, em sua Portaria no 13, de 2 de fevereiro de 1972, promove, em caráter precário, em livro próprio e mediante certificado de conclusão de curso, o registro profissional de Psicólogo.

A regulamentação da Lei no 5.766 foi outorgada pelo Senhor Presidente da República, Ernesto Geisel, a 17 de junho de 1977, através do Decreto no 79.822 .

\section{CAPÍTULO V}

\section{Encontros das sociedades de psicologia (1971 - 1973)}

Promulgada a Lei no 5.766, de 20 de dezembro de 1971, que cria os Conselhos Federal e Regionais de Psicologia, os Psicólogos brasileiros sentiram chegado o momento de se unirem em classe coesa e identificada, movidos pelo espírito da Lei, que lhes oferecia direitos profissionais privativos e imagem diferenciada e típica, diante da opinião pública.

Todas as Sociedades de Psicologia foram despertadas, de norte a sul do País, para a perquirição deste objetivo. 
Não foi fácil, nem simples e, tampouco, imediata a realização da empreitada. Percalços da mais diversa natureza tinham que ser arrostados.

Três tipos diferentes de óbices cristalizados, durante décadas, desafiavam os Psicólogos do Brasil. De uma parte, a ciência Psicológica, extremamente nova, conservara, por muito tempo, um cordão umbilical, difícil de romper-se, com a mãe Filosofia, levando a muitos, de formação estritamente especulativa, a não aceitarem a Psicologia como ciência à parte e os Psicólogos como portadores de direitos privativos. De outra parte, os profissionais de Psicologia, na cátedra ou fora dela, mourejavam isolados, caminhando quase à sombra, como a temer que o contato e a troca de experiências e opiniões lhes ameaçassem a segurança e o status adquiridos, a duras penas. A existência de grupos de trabalho formados por nomes que angariariam, por vezes, grande celebridade, funge, apenas, de exceção em meio ao isolacionismo em que viviam os Psicólogos, no desempenho de uma profissão que só, a partir de 1971, assumiria, de direito, estatura jurídica definitiva. De outra parte, a fecundidade com que a sociedade humana gerava, em nível exponencial, problemas e desajustes, em todas as áreas do comportamento, solicitou a interferência de múltiplas profissões, nas seáras dos Psicólogos, acasteladas na certeza subjetiva de que os problemas psíquicos, ou não constituíam objeto da atividade terápica, específica do Psicólogo, dentro das atribuições que a Lei outorgara, ou integravam o direito exclusivo dessa ou daquela profissão ou, ainda, eram interpretados como pertinentes a quantos de Psicologia conheciam um pouco.

E não bastasse essa anômala situação, o Psicólogo brasileiro defrontava-se com uma série de tradições menosprezadoras da sua imagem e com inúmeros estereótipos culturais, ora a impedirem seu acesso ao público preconceituoso, ora a bloquearem suas tentativas de emergir, como figura profissional característica, em meio às demais profissões, que, "per fas aut per nefas" se acreditavam credoras da administração da Psicologia.

Este estado singular de uma classe emergente se faria mais problemático, diante da distância que se criara, por imposição do tempo e da tradição, entre os nossos profissionais, o que geraria, quando da tentativa de unidade, problemas extremamente salebrosos, quais os que, mais tarde, seriam detectados ao se desencadear a necessária e urgente fiscalização do exercício profissional.

Envidando esforços dignos dos mais altos encômios, os Psicólogos brasileiros começaram a marcha em busca da unidade.

O primeiro Encontro Nacional, proposto à Associação Brasileira de Psicólogos, em fins de fevereiro de 1971, pela Direção da Sociedade Mineira de Psicologia, realiza-se, em São Paulo, a 13 e 14 de março, nas dependências do Centro Regional de Pesquisas Educacionais Professor Queiroz Filho, na Cidade Universitária. Fizeram-se representar: A Associação Brasileira de Psicólogos, a Associação Profissional de Psicólogos de São Paulo, a Sociedade de Psicologia de São Paulo, a Sociedade Mineira de Psicologia, a Sociedade de Psicologia do Distrito Federal. Não estiveram presentes, não obstante convidadas, a Sociedade de Psicologia do Rio Grande do Sul, a Sociedade de Psicologia do Rio de Janeiro e a Associação Brasileira de Psicologia Aplicada.

Presidido pelo Psicólogo Geraldo Magnani, o Encontro chegou a conclusões que definiriam os passos dos novos conclaves e das atividades a se desempenharem, com vistas à regulamentação da Lei no 5.766, à eleição e posse do Conselho Federal de Psicologia e às condutas de natureza prática e política para tais fins. 
Todas as Sociedades comprometeram-se a se manifestar, após informação da Sociedade de Psicologia do Distrito Federal, perante autoridades, parlamentares e órgãos federais.

Estudou-se a possibilidade de transformar a Associação Brasileira de Psicólogos em Associação Brasileira de Psicologia. Sob os auspícios da ABP, foi marcado o II Encontro Nacional para os dias 28 e 29 de janeiro de 1972, em Belo Horizonte e, depois, em Barbacena.

Discutem-se e assumem-se posições em relação às oportunidades de trabalho abertas pelo Conselho Nacional de Trânsito. Instituiu-se o DIA NACIONAL DO PSICÓLOGO a ser comemorado, a 27 de agosto, dia da promulgação da Lei no 4.119, sendo designada a Sociedade de Psicologia do Distrito Federal para cuidar da transformação da referida data em Lei. As Sociedades de Psicologia do Brasil aceitam elaborar um anteprojeto de decreto de regulamentação da Lei no 5.766, a ser discutido, no II Encontro.

Estava dado o primeiro e amplo passo para a integração das Sociedades de Psicologia e para a ação conjunta dos Psicólogos brasileiros em direção à posse dos seus Conselhos Federal e Regionais.

Muito caminho se haveria, entretanto, do palmilhar, a partir de então, para desobstruir de interesses e políticas contrárias àquele evento, a estrada dos profissionais de Psicologia. Mas, as Sociedades estavam motivadas e se dispunham a qualquer sacrifício.

Em Barbacena, a 28 de janeiro de 1972, no Hotel Grogotó, teve início o II Encontro Nacional das Sociedades de Psicologia, presidido pelo Psicólogo Geraldo Magnani.

Foram convidadas e enviaram representantes as seguintes Sociedades: Associação Brasileira de Psicólogos, Sociedade de Psicologia de São Paulo, Associação Profissional dos Psicólogos de São Paulo, Sociedade Mineira de Psicologia, Sociedade de Psicologia do Distrito Federal, Associação Baiana de Psicólogos, (representando "sponte sua" a Associação Pernambucana de Psicólogos), Sociedade de Psicologia do Rio de Janeiro e Associação Brasileira de Psicologia Aplicada.

Os participantes do II Encontro deliberaram: criar uma entidade nacional coordenadora das atividades das Sociedades de Psicologia, para cuja fundação foi indicado o III Encontro Nacional, a se realizar no Rio de Janeiro, durante a Semana da Pátria de 1972, sob a coordenação da Associação Brasileira de Psicologia Aplicada e a Associação Profissional dos Psicólogos da Guanabara. Quanto aos estudos para dar cunho legal ao Dia Nacional do Psicólogo, ficou decidido que não se tomaria qualquer atitude, até que se estruturasse, durante dois anos, um costume entre os Psicólogos.

Os participantes do conclave de Barbacena abordaram, ainda, o problema da aposentadoria do Psicólogo, decidindo que a Associação Profissional dos Psicólogos do Estado de São Paulo enviaria ao Senhor Ministro do Trabalho solicitação de modificação do critério de cálculo de aposentadoria do profissional liberal, incluindo o profissional de Psicologia. Em relação ao Psicotécnico para motoristas, assentiram os convencionais em dirigir carta ao CONTRAN, relatando os problemas existentes e sugerindo as melhorias cabíveis. 
Uma Comissão, constituída pelos Psicólogos Geraldo Magnani, Arrigo Leonardo Angelini e Myrian Valtrude Patittuci Neto, recebeu a incumbência de se dirigir ao Senhor Ministro do Trabalho e outras autoridades federais para tratar dos assuntos discutidos no Encontro.

Em ata foi registrado um voto de louvor à Sociedade de Psicologia do Distrito Federal, ao Senador Franco Montoro e aos Deputados Sinval Guazelli e Clovis Stenzel pelos esforços e cometimentos em prol da aprovação da Lei № 5.766 .

A partir de então, amadurecem as posições, esclarecem-se os objetivos a se perseguirem, modelam-se as atitudes a serem tomadas, assumem-se propósitos claros em direção à prática das exigências da Lei no 5.766; armam-se, com diligente e cuidadosa prudência, os modelos de ação, arquitetam-se os tipos eficientes de defesa contra ações insidiosas que, no subsolo das intenções acalentadas pelos Psicólogos, atentavam contra os diplomas legais 4.119 e 5.766 .

Os Psicólogos do Brasil unem-se, finalmente, em torno de uma mesma e única bandeira: a própria afirmação como classe e como profissão, com características privativas.

A 17 de janeiro de 1973, uma Comissão, composta pelos Psicólogos Clínicos: Elisa Dias Velloso e Therezinha Lins de Albuquerque e pelo médico psiquiátra Samuel Menezes Faro, entrega ao Senhor Ministro da Saúde, Dr. Mário Machado Lemos, um Memorial, assinado pelo Presidente da Associação Brasileira de Psicologia Aplicada, Psicólogo Aroldo Soares Rodrigues, solicitando a anexação do documento aos autos dos processos n 000918/72, 000944/72 e 000031/72, onde se contrariam e se contrastam posições explícitas daquele Ministério contrárias aos direitos do Psicólogo ao uso da Psicoterapia.

O Memorial expõe o ponto de vista da ABPA, no que tange à matéria do "Psicólogo como Psicoterapêuta", vez que, o Ministério da Saúde, através do Parecer do Dr. A. Alcântara: "Considerações sobre o Psicólogo como Terapeuta", propunha se alterasse a legislação que regulamenta a "formação e o exercício da profissão de Psicólogo.

Como se vê, as dificuldades para a caracterização da atividade privativa do Psicólogo derivavam não apenas de interesses profissionais outros, que se acreditavam lesados pela Lei no 5.766 , sobretudo em seu art. $13 \S 1 \underline{0}$, mas tinham origem em forças bem mais poderosas.

Nos dias 2 e 3 de junho, na Fundação Getúlio Vargas, Rio de Janeiro, realiza-se o /// Encontro Nacional de Sociedades de Psicologia, de onde haveria de sair, após ingentes esforços, a eleição e posse do Conselho Federal de Psicologia.

Convidadas, compareceram as: Associação Brasileira de Psicologia Aplicada, Associação Profissional dos Psicólogos do Estado da Guanabara, Associação Brasileira de Psicólogos, Associação Profissional do Estado de São Paulo, Sociedade de Psicologia de São Paulo, Sociedade Brasileira de Psicologia e Clínica Psicopatológica, Sociedade Mineira de Psicologia, Associação Baiana de Psicólogos, Associação Pernambucana de Psicólogos, Sociedade de Psicologia do Rio Grande do Sul, Associação Profissional dos Psicólogos do Rio Grande do Sul, Sociedade de Psicologia do Distrito Federal e Sociedade de Psicologia de Ribeirão Preto. 
A intensa atividade que caracterizou o III Encontro Nacional de Sociedades de Psicologia, presidido pelo Psicólogo Aroldo Soares Rodrigues, voltou-se, não obstante apreciar os itens abordados e discutidos nas reuniões de São Paulo e Barbacena, sobretudo, para o núcleo das preocupações de toda a classe, no País: a defesa dos direitos do Psicólogo, descritos na Lei no 5.766 e a urgência urgentíssima da eleição e posse do Conselho Federal.

Depois de analisados os aspectos legais da Lei no 4.119; depois de estudada a formação do Psicólogo e abordados os temas centrais da Ética Profissional, tratou a Assembléia, longa e detidamente, da importância e inadiável necessidade do Conselho Federal de Psicologia, para a sobrevivência da Classe. Para tanto, foram lembradas as posições de responsabilidade das reuniões anteriores e aprovadas novas atitudes políticas e práticas a se desdobrarem, a partir do encerramento do conclave.

Resultou evidente, em meio à consciência de coesão dos Psicólogos presentes, que uma NOVA ÉRA acabava de surgir para a Psicologia. Os Psicólogos brasileiros concertavam uma luta que se haveria de concluir, meses depois, com sua grande vitória: A DEFINIÇÃO PROFISSIONAL DE UMA CLASSE.

Dentro dos princípios ditados pela prudência, no momento histórico que se vivia, os Psicólogos, presentes ao III Encontro, continuaram a trabalhar junto às autoridades federais, segundo os modelos definidos em Assembléia, enquanto se desenvolviam os trabalhos governamentais, tendentes à escolha dos membros do novo Conselho Federal, que seriam indicados entre os representantes das Sociedades de Psicologia, participantes da reunião, na Fundação Getúlio Vargas.

\section{CAPÍTULO VI}

\section{Eleição, posse e atividades do primeiro Conselho Federal (1973 - 1976)}

Convocados pelo Senhor Ministro do Trabalho, Dr. Júlio Barata, a 19 de dezembro de 1973, compareceram a Brasília os delegados de todas as Sociedades de Psicologia, presentes ao III Encontro Nacional, e portadores dos requisitos exigidos pelo Governo.

Em contatos extra-oficiais, os delegados já haviam acertado suas deliberações e decidido seus entendimentos quanto ao que se haveria de fazer, na reunião plenária, a se realizar às 20 horas, no Edifício do SENAC, em Brasília.

Os debates se alongaram e, a pouco e pouco, o ambiente se fez tranquilo, aquiescendo os representantes das Sociedades de Psicologia em aceitar o critério de representatividade de todas as regiões do Brasil, onde houvesse maior concentração de profissionais de Psicologia, elegendo-se um Conselheiro e respectivo Suplente, para cada Região. Ficou, também, assentado que as duas Regiões com maior população de Psicólogos, (São Paulo e Rio de Janeiro) se fariam representar por dois Conselheiros e dois Suplentes.

A eleição se realizou, através de voto declarado, sendo, assim, constituído o Primeiro Conselho Federal de Psicologia: CONSELHEIROS EFETIVOS: Arrigo Leonardo Angelini (São Paulo), Arthur de Mattos Saldanha (Rio Grande do Sul), Clovis Stenzel (Rio de Janeiro), Geraldo Magnani (Minas Gerais), Geraldo Servo (Distrito Federal), Halley Alves Bessa (Minas Gerais), Oswaldo de Barros Santos (São Paulo), Tânia Maria Guimarães e Souza Monteiro (Pernambuco), Virgínia 
Leone Bicudo (Distrito Federal). CONSELHEIROS SUPLENTES: Antonio Rodrigues Soares (Bahia), Caio Flamínio Silva de Carvalho (Bahia), Myriam Waltrude Patittuci Neto (Minas Gerais), Odette Lourenção Van Kolck (São Paulo), Reinier Antonius Rozestraten (São Paulo), Rosaura Moreira Xavier (Distrito Federal).

Não se haviam, obviamente, constituído, ainda, as Regiões de Psicologia, ficando deliberado, apenas, a representatividade das Regiões Geográficas, designando-se as suplências, independentemente, de qualquer outra característica que não a da presença dos grupos maiores de Psicólogos junto ao Conselho.

Na manhã do auspicioso dia 20 de dezembro, na sede do Ministério do Trabalho, em sessão solene, o Senhor Ministro Júlio Barata dava posse ao Primeiro Conselho Federal de Psicologia.

Digna de nota é a afirmação do Senhor Ministro, em seu discurso de saudação aos novos Conselheiros, ao parabenizar e encomiar a sua eleição como uma das mais pacíficas e rápidas de que já tivera notícia. E concluía: "Não poderia ser de outra forma, em se tratando de Psicólogos".

Nascia uma classe e começava a vigir um Conselho Federal. Sobre os ombros de alguns profissionais, milhares de Psicólogos brasileiros depositavam, agora, altas e pesadas tarefas e o ônus de longas esperanças.

A tarefa era, de fato, imperativa e fatigante. Tudo deveria ser iniciado "ab ovo". O Conselho não dispunha de sede, não possuía base financeira, necessitava de Regimento Interno, carecia de legislação pertinente, precisava de estrutura administrativa, desconhecia tradição. Tudo dependia do esforço, da dedicação, da disponibilidade, sacrifício e espírito público dos eleitos.

Segundo dispositivo dos artigos 35 e 36 da Lei no 5.766, em suas Disposições Gerais e Transitórias, o Conselho Federal teve por sede inicial dependências do Ministério do Trabalho.

Primeiro ato do novo Conselho foi a eleição da sua Diretoria que ficou assim composta: Presidente: Arrigo Leonardo Angelini; Vice-Presidente: Virgínia Leone Bicudo; Secretário: Geraldo Servo; Tesoureiro: Halley Alves Bessa.

Às próprias expensas, os novos Conselheiros iniciaram um longo período legislativo, através de reuniões mensais, na Capital Federal, em obediência a quanto dispõe o art. 4o da Lei no 5.766.

Depois de criado o Regimento Interno, o Conselho Federal fixou, através da Resolução no 01/74, de 30 de abril, as zonas de jurisdição e sedes dos Conselhos Regionais. Complementando aquele diploma com a Resolução no 02/74, que fixa as atribuições dos Conselhos Regionais de Psicologia, designa o CFP os primeiros componentes desses 36 Conselhos e dá outras providências.

Ficaram, assim, distribuídos os Conselhos Regionais: $1^{\text {a }}$ Região, CRP-01, com sede em Brasília, abrangendo: Distrito Federal, Estados do Acre, Amazonas, Goiás, Pará e Territórios Federais do Amapá, Roraima e Rondônia; $2^{a}$ Região, CRP-02, com sede em Recife, abrangendo os Estados de Pernambuco, Paraíba, Alagoas, Ceará, Rio Grande do Norte, Piauí, Maranhão e Território Federal de Fernando de Noronha; $3^{a}$ Região, CRP-03, com sede em Salvador, abrangendo os 
Estados de Bahia e Sergipe: $4^{a}$ Região, CRP-04, com sede em Belo Horizonte, abrangendo os Estados de Minas Gerais e Espírito Santo; $5^{a}$ Região, CRP-05, com sede no Rio de Janeiro, abrangendo os Estados da Guanabara e Rio de Janeiro; 6 a Região, CRP-06, com sede na cidade de São Paulo, abrangendo os Estados de São Paulo e Mato Grosso; $7^{a}$ Região, CRP-07, com sede em Porto Alegre, abrangendo os Estados do Rio Grande do Sul, Santa Catarina e Paraná.

No dia 27 de agosto de 1974, Dia Nacional do Psicólogo, são empossados, solenemente, em suas respectivas Regiões, os membros dos Conselhos Regionais de Psicologia, designados pelo Conselho Federal, de acordo com o art. 38 da Lei no 5.766, em suas Disposições Gerais e Transitórias.

A Filosofia de ação deste Conselho Federal, desde os seus primeiros momentos, corporificou-se no empenho de elaboração das leis fundamentais sobre as quais se viessem a assentar, sólidas e definitivas, a tradição e a unidade da classe, recentemente reconhecida, ao lado de uma consciência de corpo, sob a égide de uma só Autarquia, tendo à frente o órgão maior, o CFP, e, no campo executivo, os sete Conselhos Regionais de Psicologia.

Não causa estranheza, por conseqüência, que, em adimplemento de sua espinhosa missão, o primeiro Conselho Federal se houvesse mantido dentro da interpretação legal, absolutamente imprescindível, dos postulados da Lei no 5.766, de 20 de dezembro de 1971.

Naquele momento, a classe dos Psicólogos contava com a respeitável cifra de 895 profissionais, atuando, no País, nas mais diversificadas áreas e, vivenciando problemas ingentes, de natureza legal, cuja solução não admitia adiamentos.

Diante dessa realidade, não se poderia exigir mais daqueles pioneiros que, arrostando o "pondus diei et aestus", rasgaram picadas, mediante Resoluções, instruções e pareceres, nos terrenos da estruturação e disciplina da Classe. Não dispunham, por isso, de tempo para quaisquer outras atividades que seriam, mais tarde, condignamente abordadas e orientadas pela afanosa ação do Segundo Conselho Federal.

É com o espírito de assentadores de marcos miliários para os passos dos Psicólogos brasileiros, que, a 1 o de julho de 1974, o Primeiro Conselho Federal adota, através de sua Resolução no 04, a definição de PSICÓLOGO, aceita pela Organização Internacional do Trabalho (OIT), como caracterização básica da profissão, num esforço de explicitar os campos de ação desse profissional e de iluminar o sentido e a dimensão do art. 13 § 10 da Lei no 5.766.

A preocupação, quase obsedante, pela integridade moral do desempenho profissional, levou o Primeiro Conselho Federal a aprovar, pela Resolução no 08, de 02 de fevereiro de 1975, o Código de Ética dos Psicólogos do Brasil, deixando, entretanto, em aberto, as discussões que se fariam imprescindíveis, ante a necessidade constante de atualização proposta pelos fatos humanos em constante mutação. Aquela Resolução seria, a 16 de outubro de 1976, aperfeiçoada por outro documento de no 14 .

Seguindo o roteiro das pressões organizacionais reclamadas pelos Conselhos Regionais e pelos profissionais de Psicologia, o Conselho Federal, após aprovar a previsão orçamentária dos CRPs para 1975, (Resolução no 07), dispõe sobre o registro dos Psicólogos, suas anuidades e multas (Resoluções no 03/74 e no 10/75), complementando esses entes legais com Instruções pertinentes (04, 05 e 10/75; e 01/76). 
Outro instrumento enriquecedor do acervo jurídico dos Conselhos Regionais, no desempenho de suas responsabilidades, foram os seus Regimentos Internos aprovados pela Resolução $\mathrm{n}$ 0 09, de 06 de março de 1975. A estes instrumentos somaram-se orientações de natureza burocrática consubstanciadas nas Instruções no 01, 02, 03, 04, 06, 07, 08, 09, de 1975; 01, 02, 03, 04, de 1976.

Na defesa do caráter privativo da atividade especificamente psicológica, descrito pelo art. 49 da Lei no 5.766, o CFP criou, com a Resolução no 19, de 20 de novembro de 1976, uma Comissão Especial de Pesquisa do Exame Psicotécnico para Motorista, buscando encontrar solução justa e digna para os problemas vividos pelos Psicólogos em todos os Departamentos de Trânsito do País.

A inexistência de aprovação definitiva, por parte do Ministério de Educação e Cultura, de alguns Cursos de Formação de Psicologia, em alguns Estados, em virtude de não satisfazerem aquelas Instituições às exigências da Lei no 5.766, criou uma situação anômala para centenas de Profissionais, a que reagiram eles com uma grita unânime pelo direito de exercício da profissão.

Depois de satisfazerem a todos os imperativos acadêmicos e, após colarem grau, na qualidade de Licenciados (Lei no 4.119), viam-se aqueles profissionais sem o título que lhes caberia pela conclusão do Curso e que não lhes podia ser conferido, porque sua Faculdade não possuía os requisitos descritos em Lei.

Em tal situação, se viessem a exercer a profissão, incorreriam em penas cominadas ao exercício profissional ilegal.

Para obviar a tal situação vexatória, o Conselho Federal de Psicologia, usando dos direitos que the conferiam a Lei e o Regimento, instituiu, com prazo definido de validade, a figura da Autorização Temporária, através das Instruções no 06 e 08 de agosto de 1975, consolidadas pela Instrução no 05, de 08 de julho de 1976.

O primeiro Conselho Federal foi também baluarte a escudar a Classe dos Psicólogos contra interferências exógenas, atentatórias à dignidade do profissional de Psicologia e à privaticidade dos seus direitos, nas áreas de sua competência peculiar. Por isso, ditou normas que atendiam aos dois objetivos intransferíveis. Dos seus estudos, se originaram as Resoluções no 18, que dispõe sobre a Fiscalização e Orientação Profissional; no 20, que estabelece princípios gerais de Fiscalização do Exame Psicotécnico para Motorista; ambas do dia 20 de novembro de 1976.

O primeiro ato, orientado à fiscalização, mesmo que anterior à Resolução específica e já presente na mente do legislador a 1ํ de dezembro de 1974, consubstanciava-se na Instrução no 02, que dispõe sobre a inscrição de pessoas jurídicas, a que se seguiu a Resolução no 13 , de 16 de outubro de 1976, que exige o Registro de Organizações destinadas à prestação de serviços psicológicos ao público.

Os muitos méritos do Primeiro Conselho Federal se completam, na área administrativa, através da aquisição, a 05 de janeiro de 1976, das salas 203, 204 e 205 do Edifício Arnaido Villares, no Setor Comercial Sul de Brasília, onde se instalou, definitivamente, a sede da Autarquia. 
Não foi sem razão que, a 1ํo de julho de 1977, falando em nome 39 do Segundo Conselho Federal, assim se expressaria o Conselheiro Antonio Rodrigues Soares, quando do descerramento de uma placa com que os novos membros do CFP passavam à História, através do bronze, os nomes dos primeiros Conselheiros do Conselho Federal de Psicologia: "Diante da simplicidade desta comemoração e da majestade deste evento. Diante da singeleza deste encontro e da grandeza desta assembléia, nada mais eu deveria expressar. Na verdade, ninguém diria que aqui se construíram feitos irrepetíveis. Ninguém diria que, neste recinto, o homem e o profissional de Psicologia foram engrandecidos, em cada ato. Ninguém diria que este ambiente singelo foi palco de pugnas, ora belicosas, ora pacificadoras, com um só objetivo: a conquista da paz da Lei e a elevação da dignidade de uma classe. Ninguém diria que a modéstia desta sala enfeitou o teatro magnífico da demonstração do mais alto espírito de dedicação à coisa pública.

Isto porque homens da mais pura cepa, tecendo o conúbio mais alto e transcendente de inteligência e coração, de lida abstrata e luta afetiva, de magnitudes de fé e excelências na consagração à causa social, aqui puseram seus pés, aqui fizeram ecoar suas vozes e aqui plantaram os produtos de suas personalidades.

Estas paredes conservam a ata perene e completa e imutável da atividade daqueles desbravadores dos ínvios caminhos, palmilhados pela Psicologia, em busca de afirmação. Neste chão, ressoam ainda as vozes dos seus passos, pesados de prudência e experiência vividas.

E foram aqueles homens pioneiros que deixaram aqui seus suores, seus cansaços, suas vigílias, sua grandeza, que, hoje, nós celebramos e exaltamos. Ao som do seu caminhar ritmado e generoso, nós caminhamos, hoje. Dentro de suas pegadas, nós queremos escrever as nossas.

Somos herdeiros seus e fazemos questão de conservar, com o mais amadurecido cuidado, os seus exemplos.

E o nosso gesto de admiração quer ter a imortalidade do vetusto bronze, sempre jovem, a dizer, no presente, as glórias do passado, e a falar, no futuro, dos cometimentos do porvir.

Queremos sentir-lhes a presença viva, o entusiasmo forte, a coragem viril. Queremos, na pletora da alegria mais esfuziante, fazer a louvação, hoje, dos que passaram, na continuidade da responsabilidade herdada e assumida, para a imortalidade da história.

E como é a História, na rigidez dos seus julgamentos e na morosidade prudente das suas certezas, a mestra da Verdade, pretendemos descerrar esta página da história da Psicologia, no Brasil, escrita na definição do bronze, a fim de que os que a lerem hoje, pensem no amanhã, e os que, amanhã, a lerem saibam que se eles são é porque estes foram". 


\section{CAPÍTULO VII}

\section{Eleição, posse e atividades do segundo Conselho Federal (1976 - 1979)}

Obtemperando à convocação que lhe fora feita pelo Presidente em exercício, Virgínia Leone Bicudo, dentro de quanto prescreve o art. 21, da Lei no 5.766, letra a), isto é, eleger os membros do Conselho Federal de Psicologia e respectivos suplentes, reuniu-se, em Brasília, a Assembléia dos Delegados Regionais, no dia 19 de dezembro de 1976.

Ao debaterem os itens da pauta de trabalhos, detiveram-se os Delegados no estudo de dois pontos fundamentais: 1. Indicação ou recondução de nomes para a constituição do Segundo Conselho Federal; 2. Eleição dos Conselheiros efetivo e suplente para representarem, no CFP, o Conselho Regional, Terceira Região, que abrange os Estados de Bahia e Sergipe. Os Conselheiros Antonio Rodrigues Soares e Caio Flamínio Silva de Carvalho, pertencentes àquele CRP, eram suplentes, durante o exercício do Primeiro Conselho Federal, de Pernambuco e Minas Gerais, respectivamente.

Após longos e interessados entendimentos e, depois de aprovado o orçamento do Conselho Federal de Psicologia para o ano de 1977, os Delegados reconduziram os Conselheiros: Arrigo Leonardo Angelini (São Paulo); Arthur de Mattos Saldanha (Rio Grande do Sul); Halley Alves Bessa (Minas Gerais); Tânia Maria Guimarães e Souza Monteiro (Pernambuco). Na mesma chapa, elegeram: João Cláudio Todorov (Distrito Federal); Marcus Vinicius Machado Vieira (Rio de Janeiro); Elisa Dias Velloso (Rio de Janeiro); Odette Lourenção Van Kolck (São Paulo); Antonio Rodrigues Soares (Bahia), na qualidade de Conselheiros Efetivos.

Os Conselheiros Suplentes eleitos foram: Albino Gonçalves Bairral Filho (Rio de Janeiro); Caio Flamínio Silva de Carvalho (Bahia); Cícero Emídio Vaz (Rio Grande do Sul); Fany Malin Tchaicovski (Rio de Janeiro); Geraldina Porto Witter (São Paulo); Maria do Carmo Vieira (Pernambuco); Mathilde Neder (São Paulo); Thereza Pontual de Lemos Mettel (Distrito Federal) e Wagner Arcioni (Minas Gerais).

Em sessão solene, às 9:30 horas, do dia 20 de dezembro, sob a presidência do Dr. Aluísio Simões de Campos, representando o Senhor Ministro do Trabalho, Dr. Arnaldo da Costa Prieto, tomou posse o Segundo Conselho Federal de Psicologia, cuja Diretoria estava assim constituída: Presidente: Arthur de Mattos Saldanha; Vice-Presidente: Tânia Maria Guimarães e Souza Monteiro; Secretário: Antonio Rodrigues Soares; Tesoureiro: Marcus Vinicius Machado Vieira.

Em seu discurso inaugural, o Presidente Arthur de Mattos Saldanha, falando em nome dos seus pares, encomiou os esforços estrênuos e as gestas ingentes de quantos construíram os alicerces da Autarquia que, no momento, se renovava, comprometendo-se a continuar a obra imponente com o mesmo espírito público e o mesmo idealismo.

A Filosofia de ação do Segundo Conselho, expressa em muitos documentos, exarados já em sua primeira reunião, pode resumir-se em três pontos fundamentais, que se haveriam de explicitar e desdobrar em centenas de textos legais, originários das densas e ativas sessões do seu Plenário:

1 - Aglutinar, em torno dos Conselhos Federal e Regionais, a classe dos Psicólogos do Brasil, dando-lhe consciência de corpo e imagem profissional estável, característica e respeitada; 
2 - Agilizar, dentro dos postulados da Lei maior e seus regulamentos, as funções específicas do Conselho Federal e dos Conselhos Regionais, em face do crescimento quantitativo e qualitativo dos profissionais de Psicologia, que se manifestava exponencial, quer pelo multiplicar-se das Escolas de Formação, quer pelos desafios inopinados das necessidades decorrentes do crescimento e desempenho profissional dos Psicólogos, quer pela interferência, nos setores privativos do Psicólogo, de pessoas de vária procedência.

3 - Tornar funcional, e cada vez mais objetiva, eficiente e eficaz, a Fiscalização do Exercício Profissional, (finalidade primeira da existência dos Conselhos, segundo a Lei), no sentido de restituir aos Psicólogos os direitos inerentes à sua competência e fazer defesas, diante do público, as prerrogativas intocáveis da sua profissão e imagem, a quantos não fossem portadores de diploma específico.

A concretização desta plataforma de atividades se faria evidente, de forma meridiana, ante o acervo de trabalhos extenuantes, cujos resultados se consolidariam nas 75 Resoluções, 142 Portarias, 27 Instruções, até hoje produzidas; nas Comissões Especiais, constituídas para o estudo dos problemas desafiadores em que labora a Classe, em áreas diversificadas de sua atuação; nos Encontros e Seminários de Psicologia e de outras profissões, em que o Conselho Federal se fez representar, no País e no exterior; nas relações com Ministérios e outros órgãos do Governo Federal, em cujos contactos, a defesa do Psicólogo foi o núcleo constante de interesses; no estabelecimento de normas para a iluminação dos limites de direito dos Profissionais de Psicologia e, finalmente, na luta, sem quartéis, para evitar insidiosas ações de quantos, até mesmo alienígenas, atentavam contra a existência e integridade dos valores profissionais dos Psicólogos do Brasil.

Para que assertos constantes daquela Filosofia de ação tivessem, de pronto, sua formalização, o Segundo Conselho, através da Portaria no 01, de 21 de dezembro de 1976, nomeou o Conselheiro Halley Alves Bessa Diretor de Publicações e Divulgações, mantendo, também, no quadro de sua administração, funcionário especializado no setor de Relações Públicas, com o intuito de fazer conhecidos a presença, produção, significado e características das funções do Psicólogo, diante da opinião pública.

Os primeiros resultados da nova Diretoria de Publicações e Divulgação vieram a lume com a criação da Revista do Conselho Federal de Psicologia: PSICOLOGIA-LEGISLAÇÃO, com dois números editados, o primeiro, em 1976; o segundo, em 1977, acervo de toda a documentação anterior à criação da Autarquia, e da produção do próprio Conselho Federal. Afeto ainda a essa Diretoria é o BOLETIM INFORMATIVO DO CFP, que já se encontra em seu oitavo número.

Sensibilizado para a sobrevivência de tudo quanto, no País, diz respeito à Psicologia, como cultura e como fonte de ciência, o Segundo Conselho terçou armas para impedir que, na maré montante da destruição da história das nossas tradições psico-pedagógicas, desaparecesse o vasto acervo da biblioteca do Centro de Orientação Juvenil (Rio de Janeiro), nomeando, mediante Portaria № 49, de 25 de outubro de 1977, a Conselheira Elisa Dias Velloso, para fazer o levantamento daquelas obras e opinar sobre sua conservação.

Dentro, ainda, desse espírito de defesa das raízes da nossa História e das características da nossa ciência, impulsionado pela motivação a uma atualização e enriquecimento objetivo da cultura específica do profissional de Psicologia, criou o Conselho Federal, em sua Portaria no 38, de 14 de agosto de 1977, uma Comissão Especial para o Estudo de um Encontro Nacional de Psicologia da Cultura, cujo planejamento seria entregue a diversos profissionais, nomeados pelas Portarias № $50 / 77$ e 53/78. 
No plano de ação para a abordagem do público, em termos de estabelecimento de um clima de informação real e fidedigna do que seja o Psicólogo e de qual conteúdo se revistam a especificidade de sua formação e atividade profissional, completa o Segundo Conselho sua iniciativa, de âmbito Nacional, editando a Portaria de no 46/77, em que nomeia Psicólogos responsáveis pelo planejamento de um Encontro Nacional de Psicologia, como Profissão. A Comissão executiva deste evento seria nomeada a 13 de maio de 1978, através da Portaria no 15. Documento com a mesma finalidade seria atribuído à Comissão de Psicologia da Cultura, a 1 o de abril de 1978, e tomaria o $\mathrm{n}^{\circ} 11$.

A mente do legislador, entretanto, a par dos seus sentimentos da alta responsabilidade, que a Lei e o cargo lhe impunham, estaria, diuturnamente, voltada para a precisação dos atributos e definições dos limites e competências do Psicólogo brasileiro, quer entre os profissionais de outras especialidades, quer nos documentos, de natureza federal, emanados, diretamente, do Governo da República. Dest'arte, várias Comissões Especiais foram criadas, para acompanhamento instante e interessado das atividades dos setores ministeriais e do poder legislativo, a fim de que, de acordo com o disposto no art. 6⿳一巛工 , letra g), da Lei no 5.766, estivessem o Conselho Federal e, consequentemente, toda a Classe dos Psicólogos, a par de quanto se produzisse ou se discutisse em relação à Profissão. Isto, com a finalidade de salvaguardar a inteireza e integridade da Lei e a honorabilidade e privaticidade dos direitos do Profissional de Psicologia.

Esta, a razão porque, a 18 de janeiro de 1977, através da Portaria no 06, era constituída a Comissão Especial para o Estudo da Participação do Psicólogo nos Projetos de Desenvolvimento de Recursos Humanos, cujo relator seria nomeado a 22 de fevereiro de 1978.

Obedecendo, ainda, à vocação que lhe derivaria das grandes linhas de ação e de direito traçadas pela Lei $n$ 오 5.766, nas amplas atribuições descritas pelo art. 6으, o Segundo Conselho constituiu, mediante Portaria no 08, de 18 de janeiro de 1977, uma Comissão Especial para o Estudo do Posicionamento do Psicólogo na Classificação Brasileira de Ocupações, cujos resultados, solicitados pelo Ministério do Trabalho, seriam a primeira contribuição de uma descrição da ação diferencial daquele Profissional, que está aguardando aperfeiçoamento que, de certo, se definirá com o crescimento da Classe e cristalização de sua imagem.

Não raras vezes, em diversos Regionais, emergem desencontros inexplicáveis de delimitação de competência, entre outros profissionais e Psicólogo, ora por treslerem o art. 13 da Lei no 4.119, de 27 de agosto de 1962; ora por conservarem, ainda, resíduos de um tempo de indefinição legal, o que suscita falsas posições de entendimento e de praxe, provocando o surgimento de percalços à livre atuação do profissional de Psicologia.

Para obviar a essa já inusitada e indevida situação, o Segundo Conselho constituiu, a 18 de outubro de 1977, pela Portaria no 07, uma Comissão Especial para o Estudo das Relações entre Orientador Educacional e Psicólogo, estendendo-Ihe, com a Portaria no 48, de 25 de outubro do mesmo ano, a atribuição de pesquisar as relações entre Psicólogo, Terapeuta Ocupacional e Assistente Social.

Novas instâncias, dentro dos mesmos imperativos, fariam aparecer a Portaria no 39, de 10 de novembro de 1978, criando uma Comissão Especial para o Estudo da Interface das atribuições do Psicólogo e do Técnico de Administração; e a Portaria no 36, de 12 de outubro do mesmo ano, designando Comissão Especial com a finalidade de caracterizar a atividade do Psicólogo, na área de Treinamento. 
Os reptos mais sérios, entretanto, a serem respondidos pelo Segundo Conselho Federal, assentar-se-iam em três amplos e complexos campos: o da assistência do profissional em formação, no que tange aos preceitos do art. 6으, letra c), da Lei no 5.766; o da Orientação e Fiscalização Profissional; e o da utilização de técnicas psicoterápicas, de vária origem, por parte de profissionais não acreditados, entre nós, segundo leis e tradições nacionais.

Estava, todavia, pleno de decisão e determinação o Segundo Conselho, em se fazer, a qualquer título e preço, o supremo responsável pelo ônus e a honra que lhe foram conferidos pelo art. 10 da multicitada Lei no 5.766; pelo art. 5으, letra b); e pelo art. $6^{\circ}$, letras b), c), d), e), f), g), j), n).

Entendendo que não se faz Psicologia, em termos profissionais, sem que a solidez de cultura, a criatividade subjetiva e competente e a execução profissional, ética e humanamente elevada, se unifiquem na pessoa adulta e responsável do profissional, e se manifeste, por isso mesmo, num respeito intocável à dignidade da pessoa humana, na sua unicidade e singularidade, o Segundo Conselho Federal de Psicologia dedicou-se, com especial afinco, a responder às necessidades de preparo profissional dos estudantes de Psicologia, através de atos que traduzem o alto descortínio dessa Autarquia Federal.

Constituiu, para consecução de tal objetivo, uma Comissão Especial para o Estudo de Currículos dos Cursos de Psicologia, passando a contribuir, pouco depois, com os esforços do DAU), (Departamento de Assuntos Universitários), para aprimoramento de tais trabalhos, mediante a presença efetiva de alguns dos, seus membros e de outros profissionais da área (Portaria no 05 , de 18 de janeiro de 1977), em seu planejamento de currículos específicos.

A 13 de maio de 1978, a Resolução no 05 definiria a figura e as funções do Auxiliar de Psicólogo, em atendimento tanto ao processo de Fiscalização Profissional, quanto à defesa da tipicidade da orientação do Psicólogo, como profissional.

Vai mais longe o alcance dos anseios do Segundo Conselho, em se fazendo presente, (pelo interesse de orientar, disciplinar e fiscalizar o exercício da Profissão), com a constituição de uma Comissão Especial, mediante Portaria no 27, de 22 de junho de 1978, para o Estudo da Situação do Ensino de Psicologia, nos Cursos de Administração, Engenharia e outros cursos superiores. Merece esclarecido que, não pretende o Conselho Federal, nas várias decisões que dizem respeito a cursos, legislar sobre sua constituição interna, seu desenvolvimento disciplinar e sua atuação departamental. Refere-se o Conselho Federal ao desempenho profissional, dentro dos imperativos descritos em Lei. Não é o estudante, em si, objeto de Resoluções e Instruções, o que compete a outros órgãos do Governo Federal, É O profissional de Psicologia que depende, no caso em análise, exclusivamente das orientações, determinações e Resoluçõóes do CFP, que, no Brasil, são Leis para a Classe. É dentro destes limites, que a Instrução n 01 , de 09 de julho de 1978, estabelece orientações sobre o credenciamento de Supervisores e os níveis de Supervisão.

O penoso e embaraçoso problema da Autorização Temporária, com que o Primeiro Conselho Federal, prudentemente, quis acudir às angústias dos Psicólogos formados em Faculdades, sem reconhecimento definitivo por parte do MEC, foi, com coragem, uma vez mais, estudado, discutido e resolvido pelo Segundo Conselho. Consciente de que o entendimento de uma figura legislada se amplia e universalisa, abraçando toda a comunidade que ela compreende e cujos atos tende a gerir; se reduz, particulariza, individualiza e pessoaliza, quando se trata de medir responsabilidades e valorar atos ou iniciativas do individuo singular; a 20 de dezembro de 1977, dispõe o CFP, através da Resolução 16, sobre os concluintes dos cursos de Psicologia reconhecidos pelo MEC e sobre a inscrição para o exercício profissional, em que a figura da 
Autorização Temporária passava a inexistir. Entretanto, não desconhecendo os aspectos de direito adquirido, de sensibilidade humana e de dimensão social, envolvidos no caso criado pelas Instituições de Formação e não pelos Psicólogos egressos delas, a 01 de abril de 1978, concede, pela Resolução no 03, Autorização Temporária, pelo prazo de 01 (hum) ano, aos Psicólogos formados por Faculdades não reconhecidas.

O primeiro documento, complementado pelo segundo, obedecia a intencionalidade sadia e beneficiadora da Classe, em seu todo: forçar as Instituições de Formação a assumirem, com rapidez, suas responsabilidades legais, perante o MEC e todos os Psicólogos em formação. O documento atingiu o desígnio e os recém-formados beneficiaram-se dos seus direitos.

O segundo repto que a realidade atiraria ao Conselho Federal: a Fiscalização do Exercício Profissional, carregaria, no entanto, em seu bojo, a tarefa mais ingente e o desempenho mais urgente. Foi ele, em todos os momentos de repensamento, discussão, atividades legislativas do Segundo Conselho o tema magno e nuclear de quanto foi pensado, discutido e produzido até esta data. E não poderia ser de outra forma. A Lei criara um Conselho Profissional e sua vocação não se especificaria, sem que se consolidassem e se dinamizassem, em pormenores, o espírito e a constância da fiscalização profissional, de que serão sempre resultado o respeito aos direitos de uma classe, a intocabilidade de sua dignidade, sua imagem, sem distorções, e a definição dos territórios de sua ação típica. Razões sobejas, por consequência, assistem ao Conselho Federal para a sua ininterrupta, perseverante e determinada preocupação pela defesa do competente exercício da profissão de Psicólogo.

Nascem, assim, Resoluções de alto significado, em que se apóiam os Conselhos Regionais e os Psicólogos, neles inscritos, para o combate a qualquer comportamento atentatório às definições legais.

Pela Resolução no 03, de 27 de fevereiro de 1977, o Conselho Federal fixa normas de Orientação e Fiscalização do Exercício Profissional do Psicólogo, revogando as disposições em contrário (Revoga a Resolução CFP no 18/76). A Portaria no 52, de 30 de dezembro de 1977, cria, para agilização de quanto se produziu até àquela data, uma Comissão Especial para o Estudo e Regulamentação da Fiscalização Profissional, trabalho que se concluiria, com grande rapidez, e seria transformado na Resolução no 01 , de 31 de janeiro de 1978, que expede normas para a Fiscalização do Exercício Profissional e institui a Comissão de Fiscalização Profissional, dando outras providências.

Traduzindo, em termos especificados, quanto a analítica Resoção referida impunha, o Segundo Conselho Federal, a 10 de junho de 1978, através da Resolução no 08, dispôs sobre o Exercício da Profissão, pelos grupos de desenvolvimento pessoal, grupos de Encontros centrados na Pessoa, grupos de Treinamento Terapêutico e equivalentes.

Perseguindo a mesma meta e buscando atender aos ininterruptos apelos da Classe, em todos os Estados da Federação, relativos à desinibida prática de Psicoterapia, em suas formas clássicas e nos modelos, não raro, mais disparatados, o Conselho Federal deu início à constituição de Processos de estudo, em seu Plenário, sobre as expressões terápicas, em todas as formas de exercício ilegal da Profissão. Muniu de instrumentos os Conselhos Regionais e lhes ofereceu, assim, meios para agirem com a rigidez que a força da Lei lhes confere.

Dispõe, inicialmente, sobre a Análise Transacional, reagindo com veemência, altivez e dignidade até mesmo à intervenção deselegante, indébita e ilegal, de organismo alienígena que, desrespeitando a norma internacional do dever de não intromissão nos assuntos de outros povos, pretendeu, infantilmente, ditar normas às normas e tradições das nossas Leis. Edita, por tal razão, 
a Resolução no 07, de 10 de junho de 1978, dispondo sobre a divulgação e emprego da Análise Transacional. A 20 de dezembro do mesmo ano, a Resolução no 19, versa sobre o mesmo tema.

Como a meia ciência é sempre fonte e repertório motivador de entusiasmos acríticos, gerando, não raro, posições extremadas e, por isso mesmo, irracionais, criou o CFP, por Portaria de no 05 , de 19 de janeiro de 1979, uma Comissão Especial para o estudo da situação da Parapsicologia, no Brasil, e, a 20 de fevereiro, fez expedir a Resolução no 04, dispondo sobre a divulgação e emprego profissionais da Psicodança, da Musicoterapia e da Expressão Corporal, e equivalentes, enquanto métodos e técnicas psicológicas.

Um problema, de dimensão nacional, continuava desafiando os esforços do Conselho Federal, não obstante as providências já tomadas pelo Primeiro Conselho: o exame psicotécnico para motorista. Com a disposição de buscar uma solução em profundidade, o Segundo Conselho procurou, como primeiro passo, fazer um estudo de natureza científica, obtendo dados, com uma amostragem significativa, colhida entre todos os Estados mais representativos, por número de Psicólogos em atividade, no setor, e entre os DETRANS, com maior percentual de pedidos de seleção, com a finalidade de conseguir resultados ponderáveis, em cuja função legislar para segurança e defesa dos direitos dos Psicólogos, diante das normas do CONTRAN. Para tanto, nomeou uma Comissão Especial de Pesquisa do Exame Psicotécnico para Motorista, credenciando, através das Portarias no 31, 32, 33, 34 e 35, de 13 de janeiro de 1977, Psicólogos, a fim de estabelecerem articulações e contatos com os DETRANS do Rio Grande do Sul, São Paulo, Rio de Janeiro, Minas Gerais e Pernambuco. A coordenação dos trabalhos de pesquisa foi confiada a uma Comissão Especial, criada pela Portaria n40, de 11 de novembro de 1978.

Os passos da ambiciosa pesquisa já se revelam alviçareiros.

Em adimplemento ao plano de esquadrinhar todos os recantos que impõem fiscalização, por parte dos CRPs, entendendo dotar os Conselhos Regionais de legislação pertinente e factível, com vistas a coibir e impedir o exercício ilegal da Profissão (pela orientação funcional do desempenho profissional e ético dos que laboram nas seáras da Psicologia, dentro dos postulados do art. 13, $\S 1$, , da Lei no 4.119), o Conselho Federal de Psicologia baixou, inicialmente, a Resolução no 04, de 14 de maio de 1977, dispondo sobre o registro de organizações destinadas à prestação de serviços psicológicos ao público e revogou a Resolução no 13/76. Um ano depois, nova Resolução, mais aprimorada e mais atual, revogaria a anterior. Intentando, ainda, aperfeiçoar os instrumentos legais, para atendimento de novas figuras que se formalizavam, nas relações entre os Conselhos Regionais e as organizações a que se referem as citadas Resoluções, foi constituída, pela Portaria no 08, de $1^{\circ}$ de abril de 1.978, uma Comissão Especial para determinação de critérios e normas para a inscrição de entidades jurídicas nos CRPs.

Os tempos clamavam por unidade de objetivos, por unificação de forças, por coesão de interesses científicos e de classe. Voltado, por vocação e dever, para este escopo, percebeu o Conselho Federal que as circunstâncias e os dados conjunturais já haviam amadurecido a ponto de, sem prejuízo de sua autonomia e identidade, as diversas Sociedades e Associações Estaduais de Psicologia caminharem para a constituição de um órgão representativo, no Brasil e no exterior. Para consecução de tal meta, criou o CFP uma Comissão Especial para o Estudo e Formação de uma Associação Nacional de Psicologia Científica, mediante a Portaria no 39, de 14 de agosto de 1977. Ante os positivos resultados colhidos por essa Comissão, a Portaria no 10, de 1o de abril de 1978, já formava outra Comissão Especial para representar o Conselho Federal de Psicologia na Assembléia Geral da Associação Brasileira de Psicologia, responsável pela aglutinação das demais Sociedades, de todo o País. Numa demonstração de apoio 
incondicional à idéia e ao fato da unificação das Sociedades, dispôs-se o Conselho Federal não só a ceder uma das salas do seu patrimônio para que ali funcionasse o novo órgão, como, também, se propôs a colaborar na publicação de uma revista de Psicologia, veículo de trabalhos científicos da nova Associação, do Conselho Federal e da Classe dos Psicólogos. A fim de ter em mãos meios facilitadores da caminhada até à realização da empreitata prevista, constituiu o CFP, através da Portaria no 25, de 22 de junho de 1978, Comissão Especial para Tratar de Assuntos Relacionados à Implementação da Associação Brasileira de Psicologia.

O ano de 1974 contava com 895 Psicólogos inscritos nos Conselhos Regionais. Este número passaria, em 1975, para 4.951. A curva evolutiva não obedecia mais, como se vê, a uma progressão aritmética. De fato, no ano seguinte, os Psicólogos já somam a alta cifra de 6.890. As Escolas de Formação aumentavam em número e suas turmas cresciam em população. $\mathrm{O}$ Conselho Federal de Psicologia não cessou de apelar para o Ministério de Educação e Cultura, através de seu órgão específico, manifestando sua preocupação ante a vertiginosa ascensão do número de formados em Cursos de Psicologia e diante da indiscriminada proliferação de novos cursos. De fato, nível cultural e solidez de formação dos novos profissionais padeceriam, de certo, em prejuízo do próprio profissional e da sua clientela. Buscou, e continua tentando, advertir aquele órgão para as consequências supervenientes de tal vegetativo crescimento, que não atende ao espírito das Leis no 4.119, de 27 de agosto de 1962 e no 5.766, de 20 de dezembro de 1971 e seus regulamentos; não atende, tampouco, às necessidades ético-sociais, diante da crise de descrédito por que passam muitas profissões. Razão suficiente para suas angústias encontrava o Conselho Federal, ao constatar que, já em 1977, as fileiras de Psicólogos engrossavam com a presença maciça de 9.233 Psicólogos em atividade, no País. Esta cifra ascenderia, em 1978, à casa dos 12.139, estimando-se que a década de 1980 verá, nada menos de 50.000 profissionais de Psicologia, trabalhando, em todas as especialidades previstas em Lei.

Diante de fatos incontestáveis, qual o desta curva exponencial de evolução da Classe, urgia se preparasse toda uma estrutura disciplinar e administrativa, capaz de suportar a abundância de problemas a demandarem soluções imediatas, por parte dos Conselhos Federal e Regionais.

A agilização de providências e legislação aderentes à realidade em desenvolvimento, nos diversos Conselhos Regionais e na cotidiana atuação dos Psicólogos, se impunha, mormente porque, antevendo a escassez de tempo e o avolumar-se de situações, sobre que legislar e orientar, dimensionava o CFP o volume de providências e a massa de documentos, que haveriam de chegar a seu Plenário para apreciação.

Situações múltiplas passam a ser objeto da produção do legislador. Uma Comissão Especial é constituída, pela Portaria no 04, de 18 de janeiro de 1977, para a Elaboração de Normas Concernentes ao Procedimento Eleitoral, cujo trabalho é aprovado e consolidado. Em Resolução de no 05, do dia 14 do mesmo mês. Instrução de no 01, do dia 16, explicitaria o documento legal.

Os Conselhos Regionais se enriqueceriam de vasto material de Resoluções e Instruções, esclarecedoras das exigências do processo administrativo. Na verdade, a Resolução no 06/77 estabelece multa para o não comparecimento injustificado às eleições; a Instrução no 05/77 esclarece sobre a vacância e provimento dos cargos de Conselheiros efetivos e suplentes; a Resolução no 10/77 dispõe sobre a prorrogação de mandatos nos CRPs e dá outras providências; a Portaria no 09/77 constitui Comissão de aquisição de imóveis, que é explicitada pela Instrução no 08/77; a Resolução no 07/77 trata do sistema de arrecadação das receitas dos Conselhos Regionais; a Instrução no 03/77, disciplina o número de reuniões mensais; a Instrução no 04/77 
estabelece normas sobre o JETON; a Instrução $n^{\circ}$ 06/77 orienta o preenchimento das carteiras profissionais; a Instrução no 07/77 dispõe sobre o levantamento geral dos CRPs e estabelece prazos; a Resolução no 09/77 dispõe sobre a frequência dos Conselheiros Regionais e Federais às Sessões e dá outras providências; a Resolução no 11/77 dispõe sobre a forma de remessa da parcela destinada ao CFP e dá outras providências; a Instrução no 09/77 traz normas sobre os bilhetes de passagens; a Resolução no 12/77 dispõe sobre a cobrança de anuidades, taxas, emolumentos e multas devidos pelos profissionais de Psicologia aos Conselhos Regionais; a Resolução no 14/77 aprova a previsão orçamentária dos CRPs para 1978; a Resolução no 13/77 refere-se às diárias dos Conselheiros Regionais; sobre a mesma matéria trata a Resolução no 03/79, em relação aos Conselheiros Federais; pela Resolução noㅜ 01/79, são revogados os dispositivos regimentais dos CRPs que dispõem sobre o recesso anual dos Conselheiros Regionais; a Resolução no 02/79 disciplina a cobrança da dívida ativa dos Conselhos Regionais; a Resolução no 05/79 introduz acréscimos no art. 89 do Regimento Interno do CFP; a Instrução no 02/78 estabelece normas para o uso das Armas Nacionais; finalmente, a Resolução no 06/79 dita normas para o cancelamento de inscrição de Psicólogo.

Evidenciava-se, a cada dia, o crescimento da Classe dos Psicólogos e agigantava-se o processo burocrático, demandando atendimento administrativo adequado às novas exigências. Também, neste campo, o Segundo Conselho se exceleu, enriquecendo seu patrimônio, pela compra, a 11 de julho de 1978, de mais uma sala no Edifício Arnaldo Villares, a de no 217. No dia 11 de agosto de 1978, o novo Plenário seria, festivamente, inaugurado com a presença dos Delegados Regionais, que, na data, se reuniram, em Brasília, para aprovação do Orçamento do CFP para 1979. Autoridades federais prestigiaram o evento.

Nem todas as instâncias da Lei no 5.766 haviam, ainda, sido postas em execução. Razões de natureza técnica, ausência de experiência específica e caráter de precedência para legislações de urgência maior, foram, prudencial mente, deixando em fase de amadurecimento alguns ditames legais. Mas, já se fazia necessário pôr em análise o art. 11 da Lei no 5.766, que se refere à categoria de Psicólogo Especialista. Apressou-se, por isso, o Conselho Federal em criar, mediante a Portaria no 30, de 13 de julho de 1977, uma Comissão Especial para o Estudo das Especialidades, tendo sido convidados todos os Conselhos Regionais a contribuírem, com seus conhecimentos, vivências e expectativas, na definitiva individuação das especialidades em que se haverá de evidenciar o trabalho dos profissionais de Psicologia, no Brasil. O próprio Regimento Interno do CFP é, na matéria, extremamente explícito, quando, em seu art. 1o, letra h) reza: "conceituar as especialidades profissionais e fixar as condições mínimas de qualificação para fins de registro de especialistas". Estava lançado mais um dos difíceis desafios que o CFP não se negava a enfrentar.

Em andamento já se encontra a observância de uma das últimas prescrições da Lei Maior a que o Segundo Conselho Federal pretende, até o final do seu exercício, satisfazer. Trata-se do disposto no art. 6, letra i) da Lei no 5.766: publicar a relação de todos os Psicólogos inscritos.

Com o intuito de tornar coesa a classe, mediante feitos de interesse comum, e despertar vocações de pesquisa, em número mais significativo, bem como premiar as fadigas dos pesquisadores isolados que, não raras vezes, permanecem no anonimato, diante da impossibilidade de fazer chegar a conhecimento público suas obras e, ainda, com o objetivo de levar a todos os centros de cultura o produto da criatividade e da dedicação de inteletos privilegiados, resolveu o Conselho Federal aprovar uma verba especial, com que premiar os melhores trabalhos de natureza científica. 
A 14 de agosto de 1977, a Portaria no 37, instituía uma Comissão Especial para estudar a criação de um Prêmio Trienal de Psicologia. Um nome deveria ser honrado com essa promoção. Nenhum outro preencheria melhor as condições de valor, pioneirismo, idealismo, criatividade e produção científica, no campo da Psicologia, que o de Manuel Bergstrom Lourenço Filho. Seu nome seria, definitivamente, lembrado pela Resolução no 02, de 02 de fevereiro de 1978, ao criar o Prêmio Trienal Lourenço Filho e seu regulamento. Como as datas para entrega, julgamento e concessão do Prêmio eram regulamentares, a 14 de setembro de 1978, a Portaria no 33 constituía uma Comissão para julgamento dos trabalhos que concorressem ao Prêmio. Razões, de natureza transitória, levariam o Conselho Federal a avocar a si, pela Resolução no17, de 19 de dezembro de 1978, a decisão de conceder ou não, naquele ano, a honraria a que se refere a Resolução no 02/78.

Não se haveriam de exaurir, entretanto, os interesses do Conselho Federal por tudo quanto dissesse respeito ao Psicólogo, sua formação e aperfeiçoamento profissional. A legislação brasileira sobre esse profissional já se mostrava, em virtude das mudanças impostas pelo tempo e evolução cultural, ora claudicante, ora ineficiente. Urgia atualizá-la e torná-la mais aderente à nossa realidade. Nas pegadas do art. 60, letra n) da Lei no 5.766, deu o CFP o primeiro passo para propor ao Poder Público alterações da legislação relativa ao exercício da profissão de Psicólogo, constituindo, através da Portaria no 42, de 18 de dezembro de 1978, uma Comissão Especial para o estudo da Legislação do Psicólogo.

A vigilância constante sobre a integridade das leis, que incorporam os dados substanciais da profissão, postulava a participação e a atenção da nossa Autarquia em quanto se criasse e se debatesse no recinto do Poder Legislativo. Para lá foi designado um Conselheiro Federal para, em caráter permanente, servir de ponto de contato, em cumprimento da letra g) do art. 6으, Lei no 5.766. Em casos específicos, qual o da abordagem de temas que, direta ou indiretamente, ferissem a Lei e direitos dos Psicólogos, estariam, desfarte, a atenção e a diligência do Conselho Federal voltados para a defesa da integridade dos nossos diplomas. Foi o que aconteceu, quando da abordagem da Psicanálise como Profissão, a que, imediatamente, responde o Conselho Federal, criando, com a Portaria no 38, de 12 de outubro de 1978, uma Comissão Especial para estudar o Projeto de Lei no 2818-A, de autoria do Deputado Odemir Furlan. Nova Comissão, na matéria, é constituída pela Portaria no 43, de 20 de dezembro de 1978, com a finalidade de implementar o plano e estratégias de ação em relação ao citado projeto.

Presidiu sempre, em toda essa fartíssima produção legal, a mente do legislador uma como inquietação incessante: conservar em nível alto o estatuto ético, espírito e forma substancial da dignidade do Psicólogo, como homem, como cienciado e como Profissional. E não poderia ser diversamente, vez que toda a ação do profissional de Psicologia, de modo direto ou indireto, dirige-se ao homem, na sua dignidade essencial. Este é objeto da atividade profissional de todas as interações profissionais, constituindo-se no alicerce diferenciador da justeza do desempenho e do respeito do Psicólogo aos postulados da dignidade e seriedade intransferíveis da ética profissional. Esta, a profunda razão porque, a 21 de dezembro de 1976, o Conselho Federal de Psicologia nomeava a sua Comissão de Ética que, entre outras atividades, está elaborando, com a contribuição dos Conselhos Regionais e dos Psicólogos Brasileiros, o nosso Código de Ética profissional, capaz de apanhar e interpretar os novos fatos comportamentais e as novas necessidades emergentes de uma Sociedade em franca transição.

Há um século, nascia a Psicologia Científica. A Tradição filosófica empírica, em cujo seio evoluiu, durante séculos, e de que se emancipou, se vincularia às contribuições da Fisiologia, a que não se reduz. Wundt estabelece a convergência entre os dados da Filosofia e os resultados das 
descobertas fisiológicas. De Fechner, utiliza o método de mensuração; de Donders, o problema dos tempos de reação; de Helmhotz, a fisiologia dos órgãos dos sentidos orientada para os problemas psicológicos. Wundt concebia a Psicologia como ciência experimental, embora, o experimento estivesse subordinado a uma concepção teórica.

Eram os primeiros passos, bem que inseguros, de uma ciência independente, que, alimentada hoje com a ajuda de ciências auxiliares, abriu horizontes para o nascimento de Escolas as mais diversas, que lhe enriquecem, com achados precisos, a textura do seu organismo científico e Ihe oferecem desafios e hipóteses de extraordinária potencialidade de achados possíveis. É uma ciência independente que, invadindo, a duras penas, as cátadras, os laboratórios, os concessos dos estudiosos e o interesse de todos os estratos do público, se impôs, com tal vigor, que já não podemos dizer ser ela a ciência do futuro, porque, no presente, é a ciência de agora.

Ao completar um século de idade, a Psicologia é herança de todos e, especificamente, é dotação nossa, impondo-nos responsabilidade de legá-la aos pósteros, mais rica, mais aperfeiçoada, mais segura e mais ciência. Aqueles, de certo, a utilizarão para o bem de uma humanidade, que, na Psicologia curiosidade pela descoberta dos eventos intrapessoais e para satisfazerem a necessidade de melhoria da teia de relações interpessoais, saciando, assim, as novas necessidades, emergentes em cada momento evolutivo por que passa o indivíduo, na busca da personalidade total.

Procurando, cum justiça, comemorar o Primeiro Centenário da Psicologia, o Conselho Federal expediu Resolução de no 18, de 20 de dezembro de 1978, estabelecendo a data de 21 de janeiro de 1979 como início das solenidades dos cem anos de vida da Psicologia, como ciência, no Brasil. Esta história teve seu primeiro capítulo com a conferência, na data, do Prof. Dr. Oscar Venâncio Ohativia, da Argentina, que traçou, para o Plenário do CFP, as linhas mestras do desenvolvimento desta ciência em seu país.

\section{CONCLUSÃO}

A resenha rápida da evolução da Psicologia, entre nós, faz-nos perceber que não foram poucos os contribuidores que plantaram idéias, ofereceram fatos, produziram dados e elaboraram situações, em cuja atmosfera viesse a se impor, entre nós, a Ciência Psicológica.

Não foram poucos, ainda, os que, pisando em solo inseguro e arrostando dificuldades impensadas, nos legaram direitos e identidade para a transformação do trabalho isolado em profissão legal e definida.

Resultado de um amanho de quase um século e meio, entre pré-história e história da Psicologia, no Brasil, é o Conselho Federal de Psicologia com seus Conselhos Regionais.

A História já está a exigir, de quantos compõem a expressiva classe dos Psicólogos brasileiros, um trabalho histórico completo, onde todos os bandeirantes dessa imensa empreitada tenham seu lugar e recebam suas honras. Deixo aqui o desafio. Talvez muitos não apareçam, nas páginas da História, mesmo que a tenham escrito nos gestos, na criação e nos atos. Todos, entretanto, no exercício da promoção do homem, objeto da Psicologia, "brilharão como estrelas nas perpétuas eternidades", que é o lugar de quantos acreditam na ciência e fazem dela a perquirição indormida da Verdade. 
Referências Bibliográficas

ALEXANDRE, Franz G. \& SELESNICK, Sheldon, T. - História da Psiquiatria, São Paulo, Ibrasa, 1968, 573 p.

AZEVEDO, Thales de. - "As polêmicas do Século XIX e a poesia cinetífica". Universitas, 1:7-29, 1968.

BAHIA. Universidade Federal. Faculdade de Medicina. Catálogo das obras de Biblioteca da Faculdade de Medicina da Bahia. Typographia do "Diário", 1876. 132 p.

BOUCHUT, Roque Spencer Maciel de. - Historie de la Medicine et des Doctrines Médicales. Paris, Libraire Germer Baillière, 1873. 2v.

CABRAL, A. C. M. - A Psicologia no Brasil, in Psicologia, n³. Boletim CXI X da Faculdade de Filosofia, Ciências e Letras da Universidade de São Paulo, 1950.

CASTIGLIONI, Arturo. — Historia da Medicina. São Paulo, Companhia Nacional., 1847. 2v.

CONI, Antonio Caldas. — A Escola Tropicalista Bahiana. Bahia, Progresso, 1952. 48 p.

COSTA, João Cruz. - Contribuição à História das Idéias no Brasil. Rio, José Olympio, 1956. 484 p.

DAREMBERG, Ch. - Histoire des Sciences Médicales. Paris, J. B. Baillière er Fils, 1870. t 2.

DIEPGEN, Paul. — História de la Medicina. 2 ed. espanola ampliada y revisada. Barcelona. Labor S.A., 1932.

ENTRALGO, Lain. História de la Medicina; Medicina moderna e contemporânea. Barcelona. Cientifico Medica, 1954. $743 \mathrm{p}$.

ESCOLA NORMAL DE SÃO PAULO. -Psychologia e Psychotechnica, São Paulo: Tipographia Siqueira, 1927.

ESCOLA SECUNDARIA DE SÃO PAULO, O Laboratório de Pedagogia Experimental, São Paulo, Typographia Siqueira, 1914.

GARRISON, Fielding h. - História de la Medicina. Trad. revisada.y completada por el Doctor Luis Augusto Mendez. $4^{\mathrm{a}}$ ed., México, Interamericana, S.A., 1966. 664 p.

KLINEBERG, O e Colaboradores. — A Psicologia Moderna. Rio de Janeiro, Livraria Agir Editora, 1953.

LIMA, Orlando de Castro. - A Medicina na Bahia no século XIX. Bahia, s.c.p.s.d 30 p.

LOPES, Octacílio de Carvalho. — A Medicina no Tempo. São Paulo, Edições Melhoramentos 1970. 339 p.

LOURENÇO FILHO, M. B. - A Psicologia no Brasil, em Azevedo, F:As Ciências no Brasil. São Paulo, Melhoramentos, 1954.

MAGALHÃES, Galeno - Doutoramento em Medicina no Brasil. Arquivos, Instituto Bahiano de História da Medicina. $6-7 ; 17-24$.

MONIZ, Gonçalo. - A Medicina e sua Evolução na Bahia. Bahia, Imprensa Oficial; 1923.115 p.

PACHECO E SILVA, A. C. - A Assistência a Psicopatas no Estado de São Paulo. São Paulo, 1945.

PESSOTTI, Isaias. — Dados para uma História da Psicologia no Brasil, em Psicologia, maio de 1975. Ano 1. n 1.

PRIMITIVO, Moacyr. - A Instrução e o Império. São Paulo. Companhia Nacional, 1936-1938. 3v.

PSICOLOGIA - LEGISLAÇÃO - Publicação Oficial do Conselho Federal de Psicologia.

SALLES, Pedro. - História da Medicina no Brasil. Belo Horizonte, O. Holman, 1971.

SANTOS FILHO, Lycurgo. - História da Medicina no Brasil (século XIX). São Paulo. Brasiliense, 1947. 2v.

SOARES, Antonio Rodrigues. - A Psicologia e o Psicólogo. Universitas, n 12/13. 1972.

SOUZA, Antonio Loureiro. - Baianos Ilustres. (1564-1925). $2^{\text {a }}$ ed. revista e aumentada, Bahia, Beneditina 1973. 347 p.

TAVARES, Luiz Henrique Dias. - História da Bahia. $4^{\text {a }}$ ed. corrigida e aumentada. Bahia. Itapuã. 164 p.

TORRES, Octávio. - Esboço Histórico dos Acontecimentos mais importantes da vida da Faculdade de Medicina da Bahia. (1808-1946).

VIEIRA, MarcuS Vinícius Machado. — Legislação que Procedeu a Concessão de Título de Psicólogo pelo MEC. (Em forma mimeografada). 